Florida International University FIU Digital Commons

$11-7-2012$

\title{
The Root of the Recycled: A Comparative Analysis of Shakespeare's "Hamlet" and the Mythological "Ur-Hamlet"
}

Isabel M. Sanchez

Florida International University, isanc018@fiu.edu

DOI: $10.25148 /$ etd.FI12120509

Follow this and additional works at: https://digitalcommons.fiu.edu/etd

\section{Recommended Citation}

Sanchez, Isabel M., "The Root of the Recycled: A Comparative Analysis of Shakespeare's "Hamlet" and the Mythological "Ur-Hamlet"" (2012). FIU Electronic Theses and Dissertations. 782.

https://digitalcommons.fiu.edu/etd/782 


\title{
FLORIDA INTERNATIONAL UNIVERSITY
}

Miami, Florida

\section{THE ROOT OF THE RECYCLED: A COMPARATIVE ANALYSIS OF SHAKESPEARE'S HAMLET AND THE MYTHOLOGICAL UR-HAMLET}

\author{
A thesis submitted in partial fulfillment of \\ the requirements for the degree of \\ MASTER OF ARTS \\ in \\ ENGLISH \\ by \\ Isabel M. Sanchez
}




\section{To: Dean Kenneth G. Furton \\ College of Arts and Sciences}

This thesis, written by Isabel M. Sanchez, and entitled The Root of the Recycled: A Comparative Analysis of Shakespeare's Hamlet and the Mythological Ur-Hamlet, having been approved in respect to style and intellectual content, is referred to you for judgment.

We have read this thesis and recommend that it be approved.

Richard Sugg

Vernon Dickson

James Sutton, Major Professor

Date of Defense: November 7, 2012

The thesis of Isabel M. Sanchez is approved.

Dean Kenneth G. Furton

College of Arts and Sciences

Dean Lakshmi N. Reddi University Graduate School

Florida International University, 2012 


\title{
ABSTRACT OF THE THESIS \\ THE ROOT OF THE RECYCLED: A COMPARATIVE ANALYSIS OF SHAKESPEARE'S \\ HAMLET AND THE MYTHOLOGICAL UR-HAMLET
}

by

\author{
Isabel M. Sanchez \\ Florida International University, 2012 \\ Miami, Florida \\ Professor James Sutton, Major Professor
}

The purpose of my thesis was to explore the problem surrounding the sources believed to constitute the Ur-Hamlet from which Shakespeare derived Hamlet. By utilization of close reading, analysis, and archetypical criticism, my thesis confirms Shakespeare's usage of the "Hero as Fool" archetype present in the Danish legend of Amleth, translated by Saxo Grammaticus and Francois Belleforest, as the Ur-Hamlet.

My study is significant because it further develops the notion that the earlier legend served as the originary source for Hamlet, while providing evidence that rejects the validity of other sources of the Ur-Hamlet. The evidence was corroborated by presenting analytical comparisons of the framework both works share. Focusing on the archetypal origins of Shakespeare's plot, characters and their actions revealed a more complex understanding of the play. These findings indicate and substantiate the claim that the Ur-Hamlet can be no other source but the Danish legend of Amleth. 


\section{TABLE OF CONTENTS}

CHAPTER

PAGE

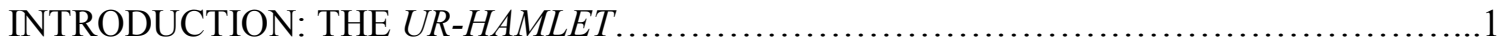

I. THE SPANISH TRAGEDY AND ANTONIO'S REVENGE ..........................

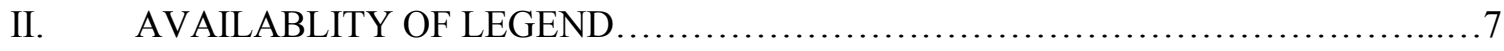

III. “THE HERO AS FOOL"

IV. RECYCLED THEMES AND MOTIFS...........................................21

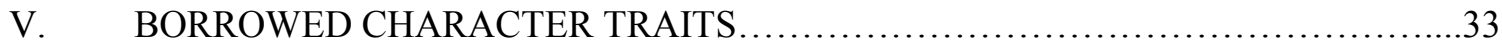

VI. ANSWERED QUESTIONS ................................................... 54

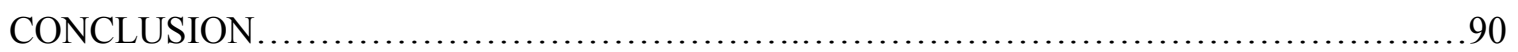

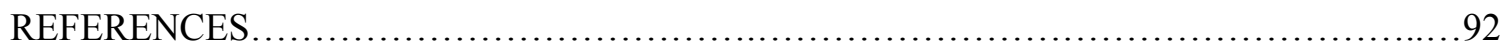




\section{INTRODUCTION}

\section{THE UR-HAMLET}

Written by William Shakespeare, Hamlet recounts the tragedy of the Prince of Denmark, whose father is murdered by his uncle, who then marries the Prince's mother. Prince Hamlet is then urged forcefully by a ghost to seek revenge, ultimately ending in his demise as well as that of his kingdom. However, the story is far from original, with playwrights John Marston and Thomas Kyd composing similar works around the same time as Shakespeare, each dealing with patricide and revenge. "It is well known that Shakespeare did not invent Hamlet's story, himself, but the nature of his sources remains obscure. Critics agree that there must have existed an 'UrHamlet,' a lost play written either by Shakespeare or some other dramatist of the period." (Sadowski 295) Therefore, scholars believe that a separate work exists, labeled the Ur-Hamlet, the inspiration for Shakespeare's version. The problem arises when trying to determine the source of the Ur-Hamlet.

Scholars generally agree on the fact that the plays by Marston and Kyd are loosely based on a text by Francois Belleforest:

"The fountain from which the Hamlet story sprang, later to be remade and elaborated by the Elizabethan playwrights, was a twelfth-century Danish chronicle by Saxo Grammaticus, the Gesta Danorum, from which a part containing Hamlet's story was made accessible to Renaissance England by way of a French author, Francois Belleforest, in whose Histories Tragiques (1570) a free translation of Saxo's Latin account appeared."

(Sadowski 296)

However, some scholars believe that a separate play existed, written before Shakespeare, Kyd, or Marston's works. "Belleforest's version was probably the source of a lost Elizabethan play... that existed by 1589 at the latest... [the play was composed] a full decade before Hamlet (ca. 15991601) and right at the outset of Shakespeare's dramatic career. The play was possibly written by Thomas Kyd (1558-94) or by Shakespeare himself." (Maxwell 519) They believe this lost play to be the Ur-Hamlet. 
Yet no version or concrete evidence of this play exists, as references to this play could very likely be pointing to Shakespeare's version. In fact, the only reference to this lost play exists in Nashe's prefatory epistle to Greene's Menaphon. Even then, scholars agree that there is no concrete proof suggesting that the particular reference points to any particular playwright. (Jack 730-31) In addition, “...this paragraph throws no light upon the authorship of the Ur-Hamlet, nor indeed is it perfectly clear that Nashe knew of a Hamlet drama" (Jack 748).

In his epistle, Nashe writes of a play with a ghost and a Hamlet character. Many believe the lost play to be the Ur-Hamlet, composed by Kyd on the basis of the text by Nashe. However, reflecting on this idea, T. W. Baldwin states,

“...[V]arious other [plays] have been attributed to Kyd, the Ur-Hamlet probably most persistently, chiefly on the strength of Nashe's well-known gibe at the play in the summer 1589. But even if Nashe should be pointing at Kyd in the same connection, he is mentioning him as only one of "a sort of shifting companions," so that Hamlet may have been written by anyone else of "these men." Besides, Nashe says "these men" have turned from Senecan plays to Italian translations, so that he is not necessarily referring to Kyd as an active playwright. Now the Ur-Hamlet, I think, we can date for this, summer 1589, its newness being the occasion of Nashe's attention... If the play does so date, then Kyd must almost certainly be freed from responsibility for it."

(Baldwin 349)

Yes, Kyd is mentioned, but not as the author of the lost play. Additionally, because of the dates, Kyd could not have been the author. Moreover, Albert E. Jack ascertains that the description of the playwrights in Nashe does not coincide with Thomas Kyd (735-7), suggesting that Nashe could have been describing anyone of a number of playwrights (733-4).

Moreover, it is important to remember that Shakespeare was writing in a time period known for inaccurate dating. Thus, the notion of a separate, lost play existing outside the realm of the above-mentioned playwrights is false, especially considering that the only "remnant" of the play lies in a brief non-dramatic recollection. The early play may never have existed, and any references to this lost play could have been alluding to Shakespeare's own Hamlet. 
Even with the elimination of the lost play, the question of the authorship of the $U r$ Hamlet still remains. So many incarnations of Hamlet exist that there must have been a singular story from which each playwright drew inspiration. Again, scholars argue that Thomas Kyd's The Spanish Tragedy or Marston's Antonio's Revenge could be this Ur-Hamlet because of the similarity of themes and characters. However, upon analyzing the three texts, the Ur-Hamlet must not be considered one of Shakespeare's contemporaries' plays.

\section{CHAPTER I}

\section{THE SPANISH TRAGEDY AND ANTONIO'S REVENGE}

While there is no concrete evidence of a mysterious, unnamed Hamlet play, there is a striking resemblance between Shakespeare's Hamlet and two other plays on stage at the time: Antonio's Revenge and The Spanish Tragedy. Scholars argue that one of these plays could have served as Shakespeare's inspiration, thus marking it the Ur-Hamlet, neglecting the more blatant similarities between the Scandinavian hero stories. However, because of the timing of the two other plays the borrowing may have been impossible. Additionally, comparing the plots reveals holes in this hypothesis. Therefore, though it is clear that Shakespeare borrowed the idea for Hamlet from some outside source, he could not have utilized his contemporaries' works.

It is important to look at the possible dates for the three plays in order to determine if Shakespeare could have feasibly read and incorporated ideas from each play into his own. While a viable date for the plays is impossible, scholars have been able to provide a range of dates for each play. Shakespeare's Hamlet was written in “...late 1599 to early 1600” (Smith, Pizer, Kaufman 494). “...[A] reasonable date for the premiere of Hamlet would be late 1600 or early 1601” (Smith, Pizer, Kaufman 495).

Antonio's Revenge is typically thought to have been written around 1599. "It is a sequel to Antonio and Mellida; the two parts were entered as one (24 October 1601) and printed together in $1602 \ldots$ Antonio's Revenge has, moreover, a prologue [that alludes to] the arrival. The question 
is, which winter: $1599-1600$ or 1600-1601" (Smith, Pizer, Kaufman 495). On the basis of the fact that it was a sequel, a reasonable date for the premiere would have been 1600-1601 (Smith, Pizer, Kaufman 496).

Therefore, both Hamlet and Antonio's Revenge were completed around the same time frame and staged as well. "Marston and Shakespeare thus must have been writing during the same period, neither able to see what the other was doing..." (Smith, Pizer, Kaufman 495). In a time period where transfer of media was not immediate, it would have been impossible for Shakespeare to have seen Marston's play and written Hamlet following Marston. Each play was created independently.

The time for the completion and production of The Spanish Tragedy is harder to ascertain. T. W. Baldwin's article entitled "On the Chronology of Thomas Kyd's Plays" dates the play anywhere between 1582 and 1585 (348). However, scholars argue that the date could have been as late as 1592 on the basis of its premiere (Greaves 708). Hamlet, then, was thought to have been written seven years after The Spanish Tragedy. There is a substantial amount of time between the two works; yet one must consider the limitations present in the time period.

The transfer of information was not immediate in the late 1500s. Additionally, the dates for the production and premiere of both Hamlet and The Spanish Tragedy are not exact; the range indicates an assumption made by scholars. Some believe that the estimate of the dates alone support the claim that the The Spanish Tragedy is the Ur-Hamlet. However, others disagree. If Kyd wrote his work seven years prior to Shakespeare, that may have been enough time for Shakespeare to produce his own version of the story. Therefore, an examination of the two play dates does not dismiss The Spanish Tragedy as a contender for the Ur-Hamlet. However, the differences between the plays themselves do.

Thus, foregoing the dating of the pieces, the plots of the plays illustrate differences that would eliminate both Antonio's Revenge and The Spanish Tragedy as contenders for the Ur- 
Hamlet. For example, in Antonio ’s Revenge, “...it would seem that a good deal of attention ought to be paid to a play in which a Ghost appears to a son, tells him that he was poisoned, and exhorts him to revenge, the son has an opportunity to stab the villain in the back but desists, with intention to gain more complete revenge later, and the hero, his mother, and the Ghost meet in a closet scene" (Smith, Pizer, Kaufman 493). The similarity to the plot of Hamlet is present, but not blatant.

Both stories maintain a strong undercurrent of revenge, both have similar titular characters, and both implement a ghost. However, the similarities end there. "Even when the parallels between Hamlet and Revenge are quite striking, the settings in which they are found may be quite different" (Smith, Pizer, Kaufman 497). Furthermore, while Hamlet ends with the death of Hamlet, Antonio lives. There is no sea voyage, and the ghost in Marston's play appears not only to the title character, but also to his wife. The similarities are there, but they do not point to a borrowing or copying of work. Additionally, Antonio's Revenge was written as a sequel. Had Shakespeare intended to create a similar work to Marston's, the world should then have evidence of a prequel to Hamlet. Instead, the plot of both plays points to copying from a third source.

“...[C]onsequently, wherever their plays agree, one may suppose that some feature of that source is thereby shadowed, however dimly" (Smith, Pizer, Kaufman 497).

Critics also argue that Shakespeare must have derived Hamlet from The Spanish Tragedy since the play also deals with revenge and utilizes a ghost. Kyd went as far as to create an embodiment of Revenge, which remains present on stage allowing the ghost of the deceased Andrea to witness actualized revenge on his murderer. Additionally, feigned and real madness is evident and the play culminates in "a play within a play" where Revenge and Andrea are finally satiated (Kyd). Again, similarities exist, but the differences prove The Spanish Tragedy as an illfitting candidate for the Ur-Hamlet. 
First of all, the ghost does not act as a catalyst for revenge. The ghost was a major point in Hamlet not represented in Kyd. Whereas in The Spanish Tragedy the play within the play ends with vengeance, Hamlet's play does not. The madness in Kyd's play is also real, and not created as a plot device as is in Hamlet. Furthermore, had Shakespeare copied Kyd, then scholars could turn to that work for explanations surrounding issues in the play, such as Hamlet's delay and feigned madness. Unfortunately, The Spanish Tragedy does not provide a basis for comparison of those themes. It cannot then be considered as basis for Shakespeare's Hamlet.

Thus, all three playwrights created similar works, but independently of one another. The dates of the plays alone prove copying to be unlikely, and the similarities within the plays do nothing to explain the extravagant plot devices Shakespeare utilizes. All three playwrights must then have borrowed from a fourth source. The mysterious, unnamed Hamlet play Nashe mentions could not have existed and most likely points to Shakespeare's Hamlet itself. A more probable source of inspiration for the playwrights lies in legends and myths popular with Elizabethans in the late 1500 s and early 1600 s.

Shakespeare's Hamlet shares more in common with the Belleforest's legends than it does with The Spanish Tragedy and Antonio's Revenge. "All that can be said for certain is that Shakespeare's version is manifestly closer to Belleforest's than to any other" (Maxwell 519). Therefore, the Ur-Hamlet critics have sought cannot possibly be Shakespeare's contemporaries' plays and instead must undeniably be found in Northern legends circulating in Shakespeare's time, stories which Shakespeare had access to. The Danish legend of Amleth is clearly one of Hamlet's predecessors, sharing various similarities with Shakespeare's play. Furthermore, upon reading the two ancient legends, the loopholes present in Shakespeare's version begin to make sense.

The term "Ur-Hamlet" has been previously used to define the “... supposed lost preShakespearean Hamlet play" (Stabler 18). This thesis changes the definition of the term, using it 
instead to refer to the legend of Amleth as the sole source for the play's inspiration. The $U r$ Hamlet, by this thesis' definition, must not be considered one of Shakespeare's contemporaries' plays; it is instead the ancient Scandinavian legend of Amleth.

\section{CHAPTER II}

\section{AVAILABILITY OF THE LEGEND}

In order to justify the claim sought by the Amleth legend as the Ur-Hamlet, it must be ascertained that Shakespeare indeed had access to it. It must also be known how this legend was accessed, and which versions were available. While not having direct access to the Northern legends of Amleth, three translations of the story were available to Shakespeare. Compiled by Saxo Grammaticus, Francois de Belleforest, and the Magnus Brothers, these versions recount the Amleth saga. Each translator added their own imaginings to the story, several of which Shakespeare chose to implement in his own.

Published in the year 1514 in Paris, France, (Maxwell 518), Saxo Grammaticus' Gesta Danorum, or History of the Danes contained a collection of oral legends amassed by Saxo himself. In it, the story of a boy feigning madness to defend himself from his usurping uncle was found in the legend Vita Amlothi. Proof of the legends abounding in Denmark exists in Saxo's own retelling. "For one thing, there are features of the story that Saxo records but certainly misunderstands" (Hansen 2). Additionally, the puns are in Danish, which leads scholars to believe it was originally transcribed in that language and translated into Latin. "In short, all the evidence indicates that the Vita Amlothi is, not literary fiction, but a literary retelling of an oral legend" (Hansen 3). Saxo's version is then indeed a collection of oral legend and myth, transferred into writing with the capacity of reaching Shakespeare.

"Saxo was the first person, so far as anyone knows, to compose a Life of Hamlet. The little biography is found in his Gesta Danorum, or History of the Danes, which he composed in 
Latin in the years around $1200 \ldots$ the story of Amleth, as Saxo calls him, is related at the end of book 3 and the beginning of book 4..." (Hansen 1). It was the earliest known narrative of the hero's life (Hansen xi). "The sagas recount the adventures of heroes who were imagined to have lived in a period before the settlement of Iceland, which began around A.S. 870" (Hansen 3). Therefore, Saxo's story is not just one of Danish origin; traces of Western Scandinavian tradition also influence his text. “... [H]is Vita Amlothi rests on a deliberate collation of information coming from more than one place. In addition, he deviated from local practice when he narrated the tale, not in his native tongue, but in the learned and international language of his day" (Hansen 4). Thus, Saxo's account becomes a rich blend of Northern legend, a combination of Danish and Icelandic story telling.

However, the legends collected by Saxo are not completely accurate retellings of Northern oral legends. While he did make every effort to collect the oral traditions, he did make slight changes while translating. The Annals of Ryd, an earlier Jutish composition which touches upon a Hamlet character, reveals some modifications imposed by Saxo. The site of Hamlet's death changes, "and it appears likely that Saxo has replaced the traditional location with one of his own' (Hansen 5). Additionally, Saxo switches the location of the kingdom from Denmark to Zealand. Evidence suggests that Saxo was himself a Zealander, again replacing tradition with his own version (Hansen 5). Albeit not a complete retelling, the changes imposed by Saxo were slight and expected when translating from one language to another.

Saxo spent time compiling the oral legends of the North, traveling throughout Scandinavia to collect his material. His work “...was well received by the learned humanists of the time and went through two more editions in the same century. His Vita Amlothi was soon retold in French by Francois de Belleforest in the fifth volume of his Histoires tragiques (1570), a popular collection of tragic tales..." (Hansen 66). However, Saxo's version was also familiar to Elizabethan and Jacobean England and could very well have been consulted by Shakespeare 
(Hansen 67). Knowing Latin, Shakespeare may have obtained a copy of the work, using it as a basis for his Hamlet. However, most likely he read the story from Belleforest, who took Saxo's version and slightly altered it, “...moralizing Amleth's revenge...” (Cary 784). Belleforest's translation could be the version Shakespeare might have had access to and would have altered further to fit the desires of his Elizabethan audience.

Belleforest's translation was widely popular as well, undergoing numerous editions in the late sixteenth and early seventeenth centuries (Hansen 66). Like Saxo, he too made slight changes to the story. For instance, it is in Belleforest's version that the Ghost makes its first appearance. "It should nevertheless interest and perhaps startle researchers and students in the field to learn that the ghost of Hamlet's father did 'appear' in one of the accepted sources of the play, the Historiques Tragiques of Francois de Belleforest" (Stabler 18). Belleforest is then credited as being the first to introduce a ghost into the Hamlet story. Additionally, Belleforest describes the Hamlet character as exhibiting melancholy, an aspect that Shakespeare carried on to his own (Stabler 18-19). His changes, though minor, "become important for the story and really interesting only when they are further developed, as we find them in Shakespeare's drama" (Hansen 66-67). Thus, one can deduce from the changes carried on that Shakespeare did have access to Belleforest's text.

Another curious change Belleforest imposed regards the age of the Hamlet character. In Belleforest, Amleth is a minor. "The 1603 Quarto, which is Shakespeare's work and the earliest known publication of a Hamlet play, indicates that Hamlet is about sixteen... [Hamlet's age] is entirely consistent in the Belleforest and First quarto editions, though ambiguous in the later Quarto and Folio editions" (Cohen 187). Shakespeare originally intended his Hamlet to be of the same age as Belleforest's, but changed the age in the later Quartos. 
Another similarity between the two works lies in the title. According to Julie Maxwell,

"All that can be said for certain is that Shakespeare's version is manifestly closer to Belleforest's than to any other... Moreover, both quarto editions (1603 and 1604) of Hamlet describe the play as a "Tragicall Historie," an exact translation of Belleforest's historie tragique. This combination of generic terms, which occurs again in Polonius' variant, "tragical-historical" (2.2.394), had never been used for a play title before and is used nowhere else in the Shakespeare canon"

Thus, not only is the storyline itself similar, the title is as well. This is another similarity that proves impossible to ignore. As stated by Maxwell, nowhere else in the Shakespeare canon can one find a title like this, a title Shakespeare clearly borrowed from Belleforest.

But why chose Belleforest? William Hansen states,

"The original playwright found in Belleforest's revenge story many features that were currently fashionable on the English tragic stage. The narrative offered murder and revenge, adultery and incest, rhetoric and moralizing, and much else to attract an English playwright in search of suitable material. Moreover, since the French retelling largely preserved the oral form of the legend, it was structured for the most part as a succession of discrete, easily visualized incidents, reported in chronological order, and so was congenial to rehandling as a drama"

Not only would it have been easy for Shakespeare to transfer the story to play form, parts of the work itself were in high demand with the Elizabethans. It would have made sense then for Shakespeare, having access to the story through Belleforest or even Saxo Grammaticus, to transfer it onto the stage.

Eventually, Belleforest's version was translated into English by Thomas Pavier and published in London, England in 1608 (Cohen 186). While this occurred seven years after the premiere of Hamlet, it is still significant. Much interest in the story of Belleforest must have existed in order for a translation to be made. Shakespeare could also have had access to a draft of Pavier's English text, although it would not have mattered, since Shakespeare could read French and could therefore comprehend and utilize Belleforest. Thus, it is evident that Shakespeare had access to the Scandinavian legends, either through Saxo Grammaticus or through Belleforest. 
Furthermore, the story was popular in England, so popular that an English translation was made of the legend after Hamlet was set on stage. The similarities between Shakespeare's version and that of Belleforest are too striking to ignore.

Belleforest was not the only author who exposed the legend of Amleth to the Elizabethans. Johannes and Olaus Magnus were Swedish brothers who wrote a work entitled "Historia de Omnibus Gothorum Sveonumque Regibus" (History of All the Kings of the Goths and Swedes). First published in Rome in 1554 and written in Latin, the history discusses several Northern legends, one of which was that of Amleth's father, Horvendil. It also includes a summary of the Amleth legend which Shakespeare could have read and could have had access to. Furthermore, Belleforest references the text in his own collection. The work was not translated into English until 1658; however, Shakespeare could read Latin, read extensively, and was known to combine different materials to mold his plays. Additionally, interest in Magnus' work remained high well past the 1560's and was in fact cited by Shakespeare's contemporaries (Maxwell 520-521). Thus, not only would Shakespeare have had access to the Amleth legend through Belleforest, he may have also had access to it through the Magnus brothers.

After the death of Olaus Magnus in 1567, another section was added, featuring more intricate historical details. "It is this combined edition that Saxo's French translator Belleforest seems to have in mind when he directs his reader to 'Voy l'historye de jean et Olaus et Grand' (see the history of Johannes and Olaus Magnus)... Shakespeare could have found, in this one volume, all the relevant passages from the Magnus works..." (Maxwell 522). While studying Belleforest, Shakespeare would have encountered that reference. Being such a popular collection, Shakespeare would have had access to it and could easily have read the Magnus brothers' history, thus utilizing it as well for his Hamlet.

But what changes designed by the Magnus brothers can one see reflected in Shakespeare? In the earlier versions, Hamlet's father, Horvendil, rules with his brother jointly. However, the 
Magnus brothers altered that. "Yet it is possible that Shakespeare derived Horvendil's status- as a king of Denmark who does not share rulership with his brother- from Johannes Magnus. Making old Hamlet (and his brother Claudius after him) King of all Denmark rather than merely governor of Jutland is often described as Shakespeare's masterstroke" (Maxwell 528-29). But it was not Shakespeare's doing. Rather, Shakespeare borrowed Magnus' version of the monarchy in the legend for his own work.

The Magnus brothers were also great naturalists, taking pains to describe the setting and environment of their characters both through written text and carved, woodcut pictures. Many of the poetic descriptions in Hamlet are a direct reflection of the Magnus brothers' careful depictions. Julie Maxwell states,

"Olaus Magnus describes how guards keep watch at night. He tells us memorably, like Shakespeare's Francisco (1.1.8.9), just how cold Scandinavia is. He describes a purgatorial rock in Iceland that seethes with perpetual fires. The spirits of those who have met a violent death emerge from their torments to fool the living, who do not yet realize they are dead. Sometimes the ghosts give, as Shakespeare's Horatio similarly suggests (1.1.136-138), foreknowledge about events that will affect their country. Olaus Magnus also recounts the same tradition as Horatio (1.1.152-61) about wandering spirits disappearing when the morning cock crows..."

The mysticism and supernatural element found in Shakespeare, which many attribute to the Elizabethans love of the metaphysical, was not totally an invention by Shakespeare to lure Elizabethans to his play. Again, this element too was borrowed from the Magnus brothers.

While this borrowing fit very well with Shakespeare's version, another borrowed aspect did not. In Act 1, scene 1, Horatio delivers the following line: "he smote the sledded Polacks on the ice" (62-63). Scholars argue as to the meaning of this line. Could Shakespeare be referring to a weapon or Polish soldiers themselves? "The phrase becomes immediately intelligible, however, if one has just been reading Olaus Magnus' account of fighting on the ice, which fills the eleventh book of his [polymathic] work. Here Shakespeare could have seen a series of vivid woodcut pictures that accompanied an astonishingly comprehensive description of northern strategies for 
war in winter" (Maxwell 539). Olaus goes on to describe the exact battle referenced in the line, shedding light on Horatio's ambiguous reference. “...[I]t may be instead that Shakespeare was drawing on the very sequence of events that the Magnus brothers considered more significant than any other. This would be a characteristic case of Shakespeare's 'unparalleled capacity for adapting, combining, and transmuting what he read"” (Maxwell 543). Yet again, comparing Shakespeare's Hamlet to the Magnus brothers' collection reveals aspects of Shakespeare's version which remained unclear. Since it has been ascertained that Shakespeare could very easily have had access to this work as well, comparing the two reveals similarities that again cannot be ignored.

Hence, Shakespeare not only had direct access to both the Magnus' brothers work but also Belleforest's translation of Saxo Grammaticus' collected stories, and perhaps even Saxo's work itself. It is also evident which elements from the stories he borrowed and took inspiration from, and these borrowed elements cannot be ignored nor written off as coincidences. It is quite probable that Shakespeare blended elements from both Belleforest and Magnus, combining each into the Hamlet tale which was set on stage. Therefore, the Ur-Hamlet sought by scholars is the collected legends of the Danish and Scandinavian people, amassed by Saxo Grammaticus, Francois de Belleforest, and Olaus and Johannes Magnus.

\section{CHAPTER III}

\section{“THE HERO AS FOOL"}

The legend of a boy feigning madness to evade certain death is not unique to one culture and it is possible that the Amleth legend Saxo compiled was actually a combination of several myths of the same nature. According to William Hansen,

"The major conclusion to which these analyses lead is that the biography of Hamlet does not stand alone as a unique Scandinavian story but is genetically related to at least two other European historical legends and that these three legends are probably collaterals. If that is correct, the Hamlet of tradition is a regional variant of a more widely known story 
whose history extends back in time over a thousand years before the first literary records of the Northern hero. This story we can call the Hero as Fool."

Thus, the Gesta Danorum, while focusing on Danish myth and history, inadvertently reveals a story found in other cultures. The "Hero as Fool" myth, which Shakespeare implemented in his Hamlet, is a variation of said myth, rewritten and reworked for the Elizabethan people.

Hero myths, including the "Hero as Fool" story, follow the same basic plot: "the hero is exposed at birth, is saved by other humans or animals, and grows up to become a national hero" (Rank vii). According to Otto Rank, a study of hero myths “... reveals a series of uniformly common features, and building from these basic elements it seems appropriate to construct a standard legend..." (47). He outlines the standard hero legend as such: The hero is born to distinguished parents (usually royalty). However, his coming is preceded be difficulties, and some sort of prophecy warns the father against the birth. The newborn child is then sentenced to death by the father through a body of water. He is saved then by animals or lowly people. After he has grown up, he finds his parents, takes revenge on his father, and is acknowledged as having greatness or fame (47). Again, the story varies from culture to culture, but similar enough aspects of the tale exist to warrant comparisons.

Incarnations of the story can be found in virtually all Indo-European cultures. "By the end of the second millennium, all of Europe, much of Anatolia, the Fertile Crescent, Iran, and much of India were dominated by people most of whom we now refer to collectively as IndoEuropeans... These peoples are the direct mythic and linguistic ancestors of much of the modern world..." (Leeming 25). The Indo-Europeans carried their myths and legends with them, spreading the stories throughout Europe. With time, the stories evolved to fit the different cultures. "Thus, in the mythologies that emerged from the various cultures that evolved over the centuries in areas originally conquered by the northern invaders we find a dominance of the proto-Indo-European themes outlined above" (Leeming 33). The legend of the "Hero as Fool" 
spread throughout, carried on the lips of Indo-European conquerors and new inhabitants, molded and sculpted to fit the folklore of each region. However, the same basic elements remained.

"The hero springs from his society, transcends that society and has a vision of the future, and ultimately returns to bring that message to his people. Campbell identifies the typical path of the hero as 'separation, initiation, and return' and identifies this pattern as the hero "monomyth" (Schwartz 83). An example of the "monomyth" can thus be seen in the "Hero as Fool" story. Comparing these heroes from various cultures reveals Campbell's pattern (Leeming 157). Additionally, the comparison also unveils the universality of the story as well as the aspects of the story themselves.

The repeated structure of both the "Hero as Fool" myth and hero legends in general prove its archetypal nature. "Generally speaking, an archetype is an original structure or plan that informs and underlies all copies made from it, so far as they are recognizable as generated from the prototype despite superficial variations in their size, shape, or material" (Sugg 76). Thus, even though variations exist in the story, the basic similarities shared show that all stories utilizing those elements draw from this archetype. Additionally, the story is riddled with archetypal themes, subjects, situations, and characters, which evoke “...a sense of its heightened significance because it represents a culturally or psychologically privileged- whether revered or condemnedobject, value, or belief" (Sugg 76).

"The earliest anthropological influence on the archetypal approach to literature was the so-called Cambridge school of comparative anthropology" (Sugg 76). The Cambridge school collected myths from a variety of cultures to trace their underlying similarities. "The general effect of their approach was to create the impression that myth and ritual the world over and through history formed regular and standard patterns" (Sugg 76). The study revealed not only this regular and standard pattern, but also similarities in characteristics: 
"...the immediacy of symbolic representation, when compared to the traditional narrative method; the intensity of an archetypal symbol, as it simultaneously embodies multiple and even paradoxical meanings, and the implicit authenticity accompany such a seemingly unplanned creation from the poet's archetypal imagination"

However, some pointed out that while these patterns were similar, the differences present in each culture undermined the similarity of meaning behind the representation.

Studying his patient's dreams, psychologist Carl Jung proposed the idea of the "collective unconscious," which provided proof that while cultures are essentially different, symbols and their representations remain the same.

"[Jung's] patients brought in dream symbols that were much more understandable when read in the light of stories and characters found in ancient world myths. To explain how $20^{\text {th }}$ century humans could dream in ancient symbols, Jung posited a deeper level of psyche, called the collective unconscious. 'Collective' meant shared by every member of the human race, and 'unconscious' meant linked to the instinctual level of the brain and, therefore, in some ways beyond the control of the unconscious and reason."

(Sugg 77)

Thus, the archetypes that reside within the collective unconscious are patterns of potential emotional and behavioral responses to possible external and internal stimuli introduced to humanity during its various stages of evolution (Sugg 77). These elements are “...prototypes rather than something gained from experience" (Sibley 1). The various hero legends then, while culturally unique, all draw from the same archetype.

Archetypes then have become an important fixture in literature. "[M]any poets and visual artists have turned to them for creative purposes, consciously incorporating them into their work" (Sugg 78). As such, applying archetypal criticism to literature allows for a more in depth understanding of the work in comparison to the more complex archetype the author was either consciously or unconsciously utilizing (Sugg 78). "A third strength of the archetypal approach is that it looks beyond the formal limits of the work itself to consider the imaginative impulse of its creator as well as to access the work's effect and affect for the reader" (Sugg 78). 
Thus, Hamlet is a representation of the archetypal "Hero as Fool" myth. Found in various Indo-European cultures, it originated as oral tradition until transcribed by translators, seeking to preserve each culture's ancient heritage. Like the anthropologists seeking a regular and standard pattern to such myths and legends, it is important to note the trajectory of the story. This trajectory proves how rooted in legend Hamlet's story is, and why Shakespeare was drawn to it. Furthermore, the abundance of "Hero as Fool" myth proves the popularity of the tale.

The earliest recorded "Hero as Fool" story originated in Rome and center around Lucius Junius Brutus. "The fullest versions of the Brutus legend that we have are the well-known Latin narrative of Livy (Histories I.39-60) from the late first century B.C. and the Greek account of Dionysios of Halikarnassos (Roman Antiquities, bk. 4) from the end of the same century... the two historians mostly agree on the course of the events..." (Hansen 25). Lucius is described as “...a young man of a capacity widely different from the assumed appearance he had put on" (Santillana and von Dechend 22). After witnessing his father's death at the hands of a man eager to remove all obstacles from the Roman throne, Lucius feigns madness to avoid detection. The king takes Lucius, now known as Brutus, in and raises him with his sons in order to serve as amusement for his children. "He took care therefore, to fashion his behavior to the resemblance of foolishness, and submitted himself and his portion to the king's rapacity" (Santillana and von Dechend 22). Eventually Brutus learns from Apollo's oracle that he is to be the next king. Shortly thereafter, Brutus discovers that the king's son has raped Lucretia, wife of Brutus' friend, and publicly vows to murder the king. It is here that Brutus' accomplices realize the madness was an act, and together they overthrow the monarchy (Hansen 27-28).

In this version, Brutus utilizes false madness in order to seek vengeance on the king. He plays the fool in order to not only protect himself until he is old enough to exact vengeance, but also to secure himself a spot in the king's court. Additionally, like in Hamlet, Brutus learns through supernatural means of his destiny and what he must do. While differing from the 
monomyth slightly, the basic story line remains involving a murderous father figure and ultimate revenge.

Another earlier version can be traced to Iran (Hansen 36). Found in the Shahnama, or the Book of Kings, written by Firdausi around A.D. 1010 (Santillana and von Dechend 36) the story involves a boy named Kai Khusrau whose father is murdered. His mother then gives birth to him at Piran, her father-in-law's, home and he is raised among shepherds. Eventually, Kai becomes a great hunter, making his own bow and arrows without using arrowheads or feathers. His father's murderer, Afrasiyab, summons him “... so that he can convince himself his victim is harmless. Although Afrasiyab has sworn solemnly not to hurt Khusrau, Piran urges the boy to play the village idiot for his own safety. When the tyrant questions him with feigned benevolence, Kai Khusrau answers... in riddles which sound senseless and indicate that young Khusrau likens himself to a dog. The usurper feels relieved: "The fellow is a fool!'" (Santillana and von Dechend 39). Khusrau is allowed to live, but must feign madness in order to avert the suspicions of his father's murderer, who is now king. Eventually, the son, by using convoluted speech, reveals to the audience his true intentions and avenges his father's murder (Hansen 36).

Again, this legend, while differing slightly from the Roman version, centers around a hero who feigns madness in order to avenge the death of his father and fix the problems brought forth by the usurper, who in this version is his own uncle. The plot follows the general storyline of "The Hero as Fool" story. While the element of the supernatural has been removed in this incarnation, the theme of revenge remains prevalent. In addition, assumed madness also plays a role in helping the young hero stay alive long enough to avenge his father's murder.

Thus, traces of Hamlet's ancestors can be found in every region where the IndoEuropean's settled, and England is no exception. In England, the "Hero as Fool" legend is manifested in "Havelok the Dane." "Most scholars place 'Havelok the Dane' at the end of the thirteenth century, between 1280 and 1290, and see it as a reworking of Anglo-Norman sources... 
The only complete manuscript of 'Havelok' appears in Bodleian MS Laud misc. 108, dated c. 1300-25" (Drake, Herzman, and Salisbury 73). "Havelok the Dane" tells the story of a boy in Denmark whose father dies. Left in the care of his father's retainer, who usurps the throne, Havelok's sisters are murdered and he is sent to his own death by the hands of a fisherman. Realizing the boy is destined to be king because of a birth mark and flames spouting from his mouth as he sleeps, the fisherman takes the boy to England and disguises him as a simple fisherman. In England, the king has died, leaving the princess in the hands of a regent who wishes to usurp the throne. Deciding that marrying her off to a fisherman will eliminate her claim to the throne, the regent arranges for Havelok and the princess to wed. However, she witnesses the same signs Havelok's foster father sees and together they go to Denmark, where Havelok overthrows the evil retainer and becomes king. He then returns to England with his wife, helps remove the false king, and accepts the English crown. Both Havelok and his wife live on and die naturally of old age (Drake, Herzman, and Salisbury 73-80).

The English version implements more of the supernatural, utilizing mystical flames to showcase Havelok's true destiny. Additionally, he exhibits marks that prove him to be royal. Rather than disguise himself as a fool, however, the hero hides among the lower class. Like the Iranian and Roman versions, the English version centers around a boy who must go into hiding, either by pretending to be a fool or of the lower class. In each story, it is only when the boy reaches a certain age that he can exact his vengeance.

While these myths were prevalent in Shakespeare's time, and he could have very well heard versions of "The Hero as Fool" tale, the version Shakespeare most likely had direct access to was that of the Vikings. "Vikings, or Norsemen, were Swedes, Danes, and Norwegians who between 780 and 1070 undertook wide-scale raids and in many cases colonization in what was, in effect, a second migration period for Germanic peoples" (Leeming 103). The Vikings moved forward and inhabited “...British Isles, found their way to Italy, Spain, and Southern France, and 
to Kiev, Constantinople, and Baghdad in the east, and probably to pre-Columbian North America in the west" (Leeming 103). It is in this wide-scale conquest that the Vikings most likely either heard and adapted "The Hero as Fool" story, or shared their version with their conquered inhabitants. It is difficult to gauge which occurred first, but it is safe to assume that a mutual borrowing occurred, resulting in the oral tradition recorded.

Their myths are preserved through Saxo Grammaticus and Icelandic historian Snorri Sturluson, who desired to maintain a record of their ancient cultures. Saxo's work corroborates that of Snorri, which was far more extensive (Leeming 103-4). "It is on the Icelander Snorri Sturluson and his sources that we depend for most of our knowledge of Germanic and Norse mythology... For his work, Snorri depended on his knowledge of Eddic and skaldic poetry and on his own talent as a saga writer, poet, historian, and antiquarian” (Leeming 104). Snorri's vast knowledge of Icelandic sagas influenced Saxo Grammaticus, who compiled the work which eventually made it into Shakespeare's hands.

Thus, in Denmark, "The Hero as Fool” becomes the story of Amleth. Rorik, the King of Denmark, placed two brothers in charge of Jutland. Fengi became envious of his brother Horvendil, murdered him, married his widow, and decided to rule Jutland alone. Fearing for his life, Amleth, Horvendil's son, played the fool. Fengi, who was not entirely convinced of his nephew's madness, decided to test him, but Amleth passed all three tests, killing Fengi's trusted adviser in the process. Deciding he should be killed, Fengi sent him along with two escorts to England with a letter proclaiming that Amleth must be put to death. Amleth intercepted the letter and altered it so that the two escorts were instead murdered upon arrival. After marrying the king of England's daughter, Amleth returned to Denmark and again donned the veil of insanity. Once the Jutes fell into a drunken stupor, Amleth set fire to the banquet hall, saving only those faithful to him and regaining the throne (Hansen 1-2). 
The Icelandic version mirrors the Amleth legend but with slight variations. In this incarnation, the hero is named Ambales. Like Amleth, Ambales continued to play the fool in order to evade capture at the hands of his father's murderer, the heathen king Faustinus. Eventually Ambales grew up and with the help of his mother, was able to murder Faustinus. He trapped the "heathens" in their chairs during a banquet, saving the Christians. Ambales also managed to regain the throne and ruled for quite some time (Hansen 2-3).

Each "Hero as Fool" story incarnation could have been a potential Ur-Hamlet, but the only one that Shakespeare had access to, definitively, was Saxo Grammaticus' version, influenced by both Snorri and the Magnus brothers, and translated by Francois Belleforest. The similarities present between the Amleth legend and Shakespeare's Hamlet are striking, so striking that the similarities cannot be ignored. Thus, the Viking version of "The Hero as Fool" legend must be then the Ur-Hamlet scholars have sought. Shakespeare certainly had access to not only Belleforest's translation of Saxo's work, but also that of the Magnus brothers as well as potentially Saxo's own version. Ease of access coupled with the popularity of the legend made evident by the various incarnations existing and the many similarities echoed in Hamlet, proves that the Ur-Hamlet was not another play; it was instead the story of Amleth.

\section{CHAPTER IV}

\section{RECYCLED THEMES AND MOTIFS}

Perhaps the most conclusive evidence that exists linking the legends to the Ur-Hamlet lies in the legends themselves. Studying "The Hero as Fool" archetype in comparison to Hamlet reveals not only similarities, but also provides explanations for the curiosities Shakespeare implemented in the text which remained unanswered at the conclusion of the play. Before delving into the characters and plot itself, the role of revenge, regicide, and the portrayal of Shakespeare's female characters must be examined to reveal answers to these curiosities which can only be explained by an archetypal critical reading. 
Revenge is a driving factor in Hamlet and the Ur-Hamlet, whose origin can then be traced to "The Hero as Fool' myth. According to Northrop Frye,

"In all revenge tragedies we need three characters (sometimes doubled or in groups): a character to be killed, a character to kill him, and an avenger to kill the killer. The revenge is usually regarded by an audience as a positive act of retribution that brings the moral norms of society into balance again, and usually sympathizes with the avenger accordingly.

(“Hamlet" 89)

Both Hamlet and the Danish legend are no different. Each is driven by this desire for revenge; their main mission in each rendition is to avenge the death of their fathers. The act of vengeance also brings forth balance to both societies. Additionally, both Hamlet and Amleth's act of murder is seen as righteous since the killer is vilified. Thus, both versions rely heavily on revenge as factors for resolution.

In the Amleth story, the murder which prompts the revenge is not hidden, as it is in

Hamlet. Amleth, as well as the entire court of Jutland, is made aware of the murder.

"Fengi burned with envy at his brother's great success, and decided to do away with him... When an opportunity came to murder him, with bloody hands he sated the lust to kill that was in his heart... He justified his crime by pretending that he had acted from good will and disguised the murder as an act of duty... The motive he alleged was accepted..."

(Hansen 97)

Pretending it to be righteous, Orvendil's murder is made known to all by his murderous brother, Fengi. However, this does not lessen Amleth's desire for revenge. He concocts a plot to avenge his father's death, one which takes a considerable amount of time to complete, and decides to feign madness until he is old enough and ready to carry out his revenge: "Amleth saw this and feared that he might make his uncle suspicious if he behaved intelligently. So he feigned madness and pretended that his mind had been damaged... “(Hansen 98). Additionally, he begins sharpening sticks, and when asked about this activity, would answer that he was "making sharp spears to avenge his father" (Hansen 98). Because of his age, and because of his lunatic actions, these remarks are taken as a jest. 
However, it is with those sticks that he plans and carries out his plan for revenge. Amleth

plots the downfall of not only his father's murderer, but also that of the nobles who stood by,

allowing the crime to go unpunished:

"In a fold of his clothing he put the sticks he had once fashioned and then went back to the room in which the nobles lay strewn all over the floor, sleeping and vomiting in their drunkenness. He cut away the supports of the hangings his mother had made, which covered the inside walls of the hall, so that they fell to the ground. He placed them upon the sleeping men, and with his crooks he bound them together so skillfully and tightly that none of the men who lay beneath was able to rise... after this he set fire to the building"

(Hansen 106)

Afterwards ensuing the deaths of those that stood by idly, he sought his uncle:

"Then he awakened his uncle and informed him that his nobles were perishing by fire, and that Amleth was there, armed with his old crooks and eager to exact the revenge he was owed for the killing of his father. On hearing this, Fengi leapt out of bed but was cut down..."

(Hansen 107)

His vengeance complete, Amleth goes on to rule Jutland, ensuing peace.

Hamlet, though not a witness of his father's murder, learns of the event through his

father's ghost. Upon the realization that his father's death was not accidental, Hamlet

immediately vows to avenge him.

"Ghost: I am thy father's spirit, doomed for a certain term to walk the night and for the day confined to fast in fires till the foul crimes done in my days of nature are burnt and purged away... List, list, $\mathrm{O}$ list! If thou didst ever thy dear father love-

Hamlet: O God!

Ghost: Revenge his foul and most unnatural murder.

Hamlet: Murder?

Ghost: Murder most foul, as in the best it is, but this most foul, strange, and unnatural. Hamlet: Haste me to know't, that I, with wings as swift as meditation or the thoughts of love, may sweep to my revenge"

(I, iv, 14-37)

Like Amleth, Hamlet decides the best course of action to pursue, until he can actualize his

revenge, is to feign madness:

“Here, as before, never, so help you mercy, how strange or odd some'er I bear myself (As I perchance herafter shall think meet to put an antic disposition on) that you, at such times, seeing me, never shall, with arms encumbered thus, or this headshake, or by 
pronouncing of some doubtful phrase... Or such ambiguous giving-out, to note that you know aught of me- this do swear..."

(I, iv, 187-202)

After adopting the veil of lunacy, Hamlet waits for the right moment to exact revenge. He is provided an opportunity while Claudius prays, but decides to continue to wait for a moment that will not allow Claudius the privilege of seeking salvation: "When he is drunk asleep, or in his rage, on in th' incestuous pleasure of his bed, at game a-swearing, or about some act that has no relish of salvation in ' $t$ - then trip him, that his heels may kick at heaven, and that his soul may be as damned and black as hell, whereto it goes" (III, iv, 94-100).

His moment finally arises while dueling Laertes. Laertes, felled by his own poisoned sword, reveals Claudius' murderous plot. Hamlet then forces Claudius to drink his own poison and stabs him with the poisoned sword: "The point envenomed too! Then, venom, to they work... Here, thou incestuous, murd'rous, damned Dane, drink off this potion. Is thy union here?” (V, II, 352-357). Hamlet dies shortly thereafter, knowing his revenge has been completed.

The revenge in both Hamlet and the Amleth legend is not acted upon immediately. Each character waits, rather than immediately seeking out justice. In Hamlet's case, he enacts his revenge only when he is sure that Claudius will not have a chance at salvation. Amleth waits until he is old enough to properly carry it out. Curiously, one of the instances Hamlet plans to wait for is when Claudius is "drunk asleep," which was the same state of being Fengi had succumbed to when he was murdered. Perhaps Shakespeare included that in Hamlet's speech as a nod to the play's predecessor.

The revenge motif in both versions is blatant, yet in and of itself, not unique to either the legend or Shakespeare. What unites both versions is the way the revenge is enacted. Both characters delay, waiting for the opportune moment, rather than lash out at their uncles. Additionally, through the revenge, the murder of the King and Jarl, respectively, is made right and the country restored to a proper ruler. In Amleth's case, he successfully murders his father's 
murderer as well as the nobles who did nothing to prevent it. He sets fire to the hall, cleansing and ensuing the sanctity of his new court. Hamlet's revenge also cleanses "rotten" Denmark.

With his dying breath, he commands Horatio to not only pass his story on, but also to crown

Fortinbras as his replacement:

"O God, Horatio, what a wounded name, things standing thus unknown, shall I leave behind me! If thou did'st ever hold me in thy heart, absent thee from felicity awhile and in this harsh world draw thy breath in pain to tell my story... But I do prophesy th'election lights on Fortinbras; he has my dying voice. So tell him, with th' occurents, more and less, which have solicited- the rest is silence..."

$(\mathrm{V}, \mathrm{ii}, 381-384,392-395)$

Assured that his story will be told, Hamlet chooses a new leader to rule in his stead. Vengeance complete, Hamlet dies and the audience is left to hear of his impending burial by Fortinbras.

Thus, the revenge not only makes right the death of both characters' fathers, but it also results in a cleansed kingdom. In Amleth's version, upon Fengi's death, he rules Jutland, fixing the corruption set forth by the usurping king. The commoners expressed different emotions upon hearing of Fengi's death: "While some of them expressed anger and some sorrow, others were secretly delighted. The former grieved for the death of their leader; the latter rejoiced that the murderer's reign had come to an end. So the onlookers responded with divided opinion to the killing of their king" (Hansen 107-8). The legend goes on to describe how Amleth proved his lunacy to be a disguise, and his eventual defeat in battle.

Hamlet's story ends with a new ruler, Fortinbras. Fortinbras shares Hamlet's thirst for revenge. His father was also murdered, but at the hands of Hamlet's father. Thus, Fortinbras seeks to avenge his father's death by attacking Denmark. An ancestor to Fortinbras does not exist in Saxo, however. On the matter, William H. Lawrence states,

"He is of special interest because... he plays no part in the pages of Saxo Grammaticus or Belleforest. He is apparently a distinctively English and distinctively dramatic addition to the story. He serves an important purpose: a distinguished person is needed to succeed to the Danish throne, to close the action with a formal speech, and, as a matter of stage necessity, to see that Hamlet is born honorably to his bier, and the dead bodies carried 
off. The final catastrophe and the events following it in the old story were quite unsuited to the theater."

(“Hamlet and Fortinbras" 673)

Shakespeare's tragedy called for the death of Hamlet after his enactment of revenge. However, Shakespeare still chose to follow the model set forth by Saxo and the Magnus brothers, in which the revenge did not result in the death of the hero and rather set him as his country's rightful ruler. Since Hamlet, because of the conventions set forth by Shakespeare, could not rule, a new ruler needed to be implemented. Fortinbras thus is introduced to the play, vaguely at first, until finally he appears just as Hamlet dies. Denmark needed a ruler; however, Shakespeare also needed his protagonist to die in order for Hamlet to be considered a true tragedy. Therefore, the implementation of Fortinbras is Shakespeare's means of continuing the tradition set forth by the Icelandic and Danish legends.

Hamlet compares himself to Fortinbras just before boarding the ship to England, noting the similarities in their circumstances as well as how apt Fortinbras seems for the challenge:

"Examples gross as earth exhort me: witness this army of such mass and charge, led by a delicate and tender prince, whose spirit with divine ambition puffed makes mouths at the invisible event, exposing what is mortal and unsure to all that fortune, death, and danger dare, even for an eggshell."

(IV, iv, 49-56)

On the comparison, Lawrence states, "This contrast is all the more striking because of the similarity in the fortunes of the two men. The Norwegian prince is the legitimate heir to a crown, but supplanted on the throne by his uncle; he is young, gifted, and ambitious; he burns to avenge the death of his father, and in this again he is thwarted by his uncle" ("Hamlet and Fortinbras" 687). Thus Shakespeare creates a character sharing Hamlet's dilemma that can do what Hamlet cannot: rule Denmark.

The legend calls for an ending which allows the revenge to be carried out, as well as the kingdom to be set right. Shakespeare cannot implement that in his own story, so he creates Fortinbras, a new Hamlet, who is also spurred by revenge. Comparing Fortinbras to post-revenge 
Amleth yields similarities which point to the legend of Amleth as the Ur-Hamlet. Shakespeare could have possibly ended his play with the death of Hamlet, never mentioning Fortinbras. However, in order to match his version to its predecessor, he needed to leave the land with a ruler.

Thus, both Hamlet and the legend of Amleth utilize revenge for the same means. Not only is it a defining motive for both main characters, both stories carry out the act similarly. Amleth and Hamlet wait until the precise moment, and each act redefines the country, removing the usurper and those who support him. Additionally, juxtaposing both versions' treatment of revenge reveals a similar chain of events, highlighting the significance of Fortinbras as Hamlet's replacement.

The act of regicide that prompted the revenge is also vital to both Hamlet and the story of Amleth. While both versions focus on their main characters' quest to avenge their fathers, this more heinous crime becomes secondary. In each version, the ruler has been murdered and is supplanted by his brother, who in turn marries his wife. Neither is brought to justice for their crime until the enactment of revenge by their nephews. In the Amleth legend, King Rorik assigns both Orvendil and Fengi to defend Jutland. Orvendil achieves greatness on the battle field, and is given Rorik's daughter Geruth as a bride. Fengi, in a jealous rage, murders his brother and marries Geruth in order to solidify his claim as sole ruler of Jutland: "Then he added incest to fratricide by taking the wife of the brother he had butchered... Without delay Fengi shamelessly embraced his wife with arms that had murdered, following up one outrageous crime with another" (Hansen 97).

In the legend, the murder of Orvendil is known by all, but Fengi “...justified his crime by pretended he had acted from good will and disguised the murder as an act of duty" (Hansen 97). However, the audience knows it is jealousy that sparked the murder, not duty. The previous section of the legend tells of great success Orvendil met on the battle field, causing Fengi to "burn 
with envy." Accepting his reasons for the murder, Jutland fails to enact justice and allows Fengi to rule.

In Hamlet, however, Hamlet suspects foul play and is deeply bothered by the speed at which his mother and uncle's wedding took place, laying the blame fully on his mother:

"...But two moths dead-nay, not so much, not two. So excellent a king, that was to this Hyperion to a satyr; so loving to my mother that he might not beteem the winds of heaven visit her face too roughly. Heaven and earth, must I remember? Why, she would hang on him as if increase of appetite had grown by what it fed on. And yet, within a month (Let me not think on 't; frailty, thy name is woman!), a little month, or ere those shoes were old with which she followed my poor father's body... O, most wicked speed, to post with such dexterity to incestuous sheets!"

(I, ii, 142-162)

At this point, Hamlet does not question his father's death, yet fears the worst.

His suspicions are not confirmed until the Ghost tells his story: "Sleeping within my orchard, my custom always of the afternoon, upon my secure hour thy uncle stole, with juice of cursed hebona in a vial, and in the porches of my ears did pour the leprous distilment..." (I, iv, 66-71). Upon discovering the truth, Hamlet vows to avenge the crime committed to the kingdom. It is perplexing, however, that the Danish court sees nothing suspicious with both the unexplained death of King Hamlet as well as the hasty marriage. The only one who questions the move is Hamlet.

Again, elements from the original story that Shakespeare left out leave questions for his readers. Why did the Danish court see nothing amiss with Claudius' rise to the throne, as well as his marriage to Gertrude? Additionally, why was Hamlet not made king in his father's place? In the Danish legend, Amleth does not rule because he simply is too young. Furthermore, the regicide is made public, but made to look as if it were committed for the good of the kingdom. Shakespeare left those questions unanswered; however, comparing Hamlet to the oral tradition wields answers. The regicide in Hamlet is left unquestioned by the other characters because the other characters were based on the Danish legend, and they do not question the regicide because 
they are provided a reason for it. Hamlet does not rule because his predecessor was too young to rule. Shakespeare could not match the age of his Hamlet to Amleth because it would not have made sense, production-wise.

Another question which arises deals with the portrayal of women in Hamlet. In Hamlet, the reader is never made aware of Gertrude's position on the matter of the regicide. One is left to wonder if she willingly chose the wedding, or was coerced into it. On the basis of Hamlet's soliloquy, her marriage to his father seemed happy. By continuing to follow the trend in Hamlet to utilize elements from the Ur-Hamlet, the Amleth legend, then it may be that Gertrude remained innocent in the matter.

Hamlet's treatment of both Gertrude and Ophelia also raises questions. Neither receive polite treatment from Hamlet, nor are portrayed in a favorable light by Shakespeare. However, how much of this is carried over from the original version? In the legend, the Ophelia character plays a part in saving Hamlet's life. Not only is she made aware of the false madness put on by Amleth, knowing this, she denies his sanity to his would be killers. Amleth's mother is viewed as someone needing rescue. Why then, did Shakespeare alter this for his version?

In Saxo's retelling, Geruth is presented as "so gentle that she would not hurt anyone, even slightly" (Hansen 97), and is portrayed as a victim by Fengi to Orvendil's imagined temper. Further into the story, however, Geruth's character takes a turn for the worse. After watching her son slay an eavesdropper in her room, she cried out and wept. Amleth responded to her cries by chastising her compliance with Fengi and reminding her of her former husband:

"Shameless woman, why do you try to conceal your immense crime with false tears? You revel like a whore in this abominable marriage of yours, incestuously embracing your husband's murderer and filthily caressing and fawning upon the man who slew the father of your son... By your actions you show that you have wholly forgotten your former husband."

(Hansen 102) 
Saxo goes on to describe how "[w]ith these reproaches he wounded his mother and brought her back to a life of honor, showing her that her former passion was better than her current delights" (Hansen 102). His mother goes on to assist him in his revenge.

Thus, in the Danish story, Geruth, while not actively conspiring in the murder of her husband, does acquiesce and revel with her husband's murderer. Amleth speaks sharply to her in her own room and is able to bring his mother to reason. She makes no further appearance in the story, but it is clear that she realizes the err of her behavior after Amleth chastises her and does play a crucial rule in his enactment of revenge.

An almost identical scene plays out in Hamlet. After witnessing the death of Polonius, Gertrude too cries out:

"Gertrude: $\mathrm{O}$, what a rash and bloody deed is this! Hamlet: A bloody deed- almost as bad, good mother, as kill a king and marry with his brother.

Gertrude: As kill a king?"

Having voiced his displeasure towards his mother's actions, he continues berating her:

"Such an act that blurs the grace and blush of modesty, calls virtue hypocrite, takes off the rose from the fair forehead of an innocent love and sets a blister there, makes marriage vows as false as dicer's oaths- $\mathrm{O}$, such a deed as from the boyd of contraction plucks the very soul, and sweet religion makes a rhapsody of words! Heaven's face does glow o'er this solidity and compound mass with heated visage, as against the doom, is through-sick at the act..."

(III, iv, 49-60)

Shakespeare pushes this confrontation to further hostility by having Hamlet show Gertrude a picture of his father and of Claudius, comparing the two, highlighting Claudius' flaws. Gertrude implores Hamlet to cease, stating, “Thou turn'st my eyes into my very soul, and there I see such black and grained spots as will not leave their tinct" (III, iv, 100-103). After a visitation from the Ghost, which eludes Gertrude, she vows to keep the outcome of their encounter secret: "Be thou assured, if words be made of breath and breath of life, I have no life to breathe what thou hast 
said to me" (III, iv, 219-221). Unfortunately, in the next scene she reveals to Claudius what occurred in her bed chamber, which ultimately leads to Hamlet's forced voyage to England.

Hamlet has justifiable cause for the harsh treatment he inflicts upon his mother. In both versions, Hamlet and Amleth feel compelled to chastise their mothers, urging them to see the err of their ways. Additionally, in both versions, Gertrude and Geruth repent. In the Danish legend, however, no more of Amleth's mother is revealed and the audience is left to believe that she went on to change her ways as promised to Amleth. In Shakespeare's version, she does not. Why then, does Shakespeare have Gertrude betray Hamlet in such a foul way?

After the confrontation in Saxo, Amleth goes on a year-long sea voyage, planned by Fengi. For Shakespeare, there needed to be a clear reason for his Hamlet to embark on this same journey. He decides to have Hamlet's mother betray him to Claudius. After hearing of what occurred, Claudius decides to send Hamlet away quickly in order to give himself time to explain the death of Polonius as well as attempt to murder Hamlet. Had Gertrude not revealed what had occurred, Claudius would have not had a solid reason for sending his nephew away. Again, examining the Ur-Hamlet provides a reason for Shakespeare's less than ideal portrayal of motherhood.

While Gertrude does betray her son, Ophelia remains steadfast in her love. Both her and her predecessor care for Hamlet and Amleth. Shakespeare attempts to give Ophelia more depth than she receives in Amleth's story, yet ends up with a weak female character who ultimately commits suicide. There is only one mention of the Ophelia character in the Danish legend. All we know of her is that "[t]hey had the same foster parents in infancy, and the fellowship of their early rearing made the girl feel a strong friendship for Amleth" (Hansen 100). She is used by Fengi as a means of unveiling Amleth's lunacy. However, she never reveals anything about him and is not mentioned again after that instance. 
Ophelia is used in a similar fashion as a test for Hamlet. Suspecting the ploy, he insults her, stating, "I did love you once" (III, I, 125), then changing it to, "I loved you not" (129). He tells her,

"Get thee to a nunnery. Why wouldst thou be a breeder of sinners... Go thy ways to a nunnery... If thou dodst marry, I'll give thee this plague for thy dowry: be thou as chaste as ice, as purse as snow, thou shalt not escape calumny. Get thee to a nunnery, farewell.

Or if thou wilt needs marry, marry a fool, for wise men know well enough what monsters you make of them “"

$(130-140,146-151)$

These words, as well as Hamlet's actions, ultimately lead to Ophelia's suicide. Since her predecessor played no major role in legend, then Shakespeare had no choice but to erase her slowly from the story line, eventually having her die off-stage. Her only role in the Ur-Hamlet was to serve as a test to Amleth. Shakespeare needed to provide her with a history in facilitate her implementation in his version. He could not have tested Hamlet's resolve to be mad with a random female character; she needed to be someone Hamlet had at one point cared about to further drive his resolve to play the fool. However, Hamlet's harsh treatment of her is not a reflection of Amleth's treatment of his foster-sister. Why then did Shakespeare not only condemn Ophelia to death, but also provide Hamlet with unnecessary barbs to throw at her?

Saxo does mention another woman whom Amleth marries while in England, Herminthrud. Later on in the story, after he enacts his vengeance, Herminthrud breaks a vow to Amleth: "For when Amleth had fallen in battle with Viglek in Jutland, she yielded herself to be the victor's spoil and share his bed' (Hansen 117). Saxo goes on to berate all women, stating, "All vows of women become void with changes in fortune, are dissolved by the shifting of time, and disappear with the play of fate, for their faith stands on slippery feet. Though they are quick to promise you something, they are slow to keep it. Slaves of pleasure, they leap headfirst and gaping in their continual longing for something new, and forget the old."

(Hansen 117)

Echoes of this show in Hamlet. Herminthrud's betrayal of Amleth, while happening after the revenge is completed, is reflected in Shakespeare. The harsh treatment Hamlet bestows on 
Ophelia must then stem from the betrayal of Amleth by his wife. Rather than have Hamlet return from England with a wife, which would result in a cessation of the revenge plot in order to introduce and explain this new female character, Shakespeare mounts on Ophelia the feelings of betrayal Amleth felt by his own wife. Thus, Hamlet's demands of Ophelia to enter a nunnery become clear. Hamlet is echoing the feelings portrayed by Amleth when his love interest eventually betrayed him.

Ophelia then becomes an amalgamation of the female characters Amleth encounters. She is used as a tool to unveil Hamlet's lunacy, and additionally, she is a used as a means for Hamlet to voice the thoughts his predecessor eventually concluded in regards to women. Shakespeare's harsh treatment of his female characters is thus provided reason when compared to the $U r$ -

Hamlet. Gertrude must betray her son in order for the sea voyage, prominent in the Amleth story, to take place, and Ophelia becomes a tool to test Hamlet, and a reminder of the eventual frailty all women succumb to, causing vows to be dissolved.

Since Shakespeare was dealing with a different medium than that of Saxo and Belleforest, the motifs of revenge and regicide are at times unclear, as well as the treatment of his female characters by Hamlet. Again though, by studying the Ur-Hamlet, comparing Saxo and Belleforest, as well as the Magnus brothers, to Shakespeare's version reveals not only striking similarities, but also the answer to several of Shakespeare's unanswered questions.

\section{CHAPTER V}

\section{BORROWED CHARACTER TRAITS}

In addition to the themes of revenge and regicide, and the harsh treatment surrounding the female characters, the characters themselves in Hamlet echo the sentiments and actions shared and exhibited by their predecessors in the Ur-Hamlet, which in and of themselves are manifestations of "The Hero as Fool" archetype. Shakespeare's characters are themselves typical representations of the characters found in this archetype. According to Northrop Frye, 
"Hence when we speak of typical characters, we are not trying to reduce lifelike characters to stock types, though we are certainly are suggesting that the sentimental notion of an antithesis between lifelike character and the stock type is a vulgar error. All lifelike characters, whether in drama or fiction, owe their consistency to the appropriateness of the stock type which belongs to their dramatic function. That stock type is not the character but it is as necessary to the character as a skeleton to the actor who plays it"

(Frye, Anatomy 172)

Thus, an archetypal critical reading of Hamlet does not provide for a reduction of the role of each character. Rather, it provides a means for understanding the complexities present in each characters' archetype that Shakespeare may have failed to illustrate. Again, an archetypal approach to Hamlet allows one to transcend the formal limits of the work, considering Shakespeare's imaginative impulses (Sugg 78).

At times, because of Shakespeare's alterations, their actions and behaviors lead to questions. One can better appreciate the complexity of these characters by comparing each to their predecessor in the Ur-Hamlet. Each character can trace their roots back to the Danish saga; however, problems emerge when these character traits come in contact with the genre. The characters of Hamlet, Claudius, and Ophelia especially illustrate this phenomenon, and a comparison to their counterparts in the Danish legend serves as evidence of the story's legitimacy as the Ur-Hamlet.

The play's titular character, Hamlet, shares much in common with his Danish predecessor, Amleth. Each suffer a similar tragedy, resulting in deceptive madness as well as eventual revenge. The matter of Hamlet's delay and feigned madness will be delved into in the subsequent chapters. For now, a basic comparison between Hamlet and Amleth will be discussed.

First of all, the similarities between their names in and of itself is striking. "Hamlet" and "Amleth" are remarkably similar. In her article "Hamlet Recycled, or the Tragical History of the Prince's Prints," Louise Cary examines the etymological significance of the names:

"The name 'Hamlet' closely resembles the name 'Amleth' and is easily glossed as an Anglicization of the Danish. But the two are not identical; Amleth loses its propriety, its 
particularity, in Hamlet, and it does so in a fascinating way. The final $\mathrm{H}$ refuses its ultimate position and moves instead to the beginning of the word. In doing so, its function changes. Fully aspirated, it now initiates the linguistic action of the rest of the name. The alphabetic character circulates, revolves and metamorphoses Amleth into Hamlet: the old parts are all there, so the memory lingers, but Amleth is no longer iterable."

While the names are not identical, both utilize the same letters, with the name "Hamlet" serving as a reflection of the outdated "Amleth." Cary goes on to describe this etymological revolution present in "Hamlet," stating, "Viewed from a different perspective, the propriety of the name Hamlet is hardly particular, because it disguises, but fails to conceal, the name Amleth. The evolution of the new name is therefore a function of the revolution of the old one. Amleth is Hamlet in potentia; Hamlet re-marks, re-inscribes Amleth" (784). Without discussing the similarities present in their character, the names themselves serve as a reminder that Shakespeare's Hamlet is a metamorphoses of the Danish Amleth, his inspiration and source for the play.

While there exists a slight difference in their names, there is a larger discrepancy in regards to their age. Amleth is introduced in both Saxo and Belleforest as a child, too young to avenge his father or save himself from his uncle. "The narrative versions of the story adhere to the usual practice of oral narrators in presenting the story chronologically from start to finish. Saxo and Belleforest slowly build up to the initial villainy and gradually relax after the revenge" (Hansen 69). Thus, the story of Amleth begins with the story of his father, and builds from there. The audience is then presented with the birth of Amleth, immediately followed by his father's murder, with no events occurring between. Yet, some years must pass between the two events. At the time of the murder, Amleth is mature enough to understand the events occurring and create a defensive plan. Amleth's age can therefore be assumed to be that of a child, old enough to understand his circumstances but not old enough to act. 
While the Danish legend follows the chronological format present in oral traditions, Shakespeare does not, choosing to begin his version in media res. Shakespeare chooses to omit the history of King Hamlet's reign as well as the actual account of his murder. Because of this, Hamlet appears on stage already a man. In Act III, scene ii, the Player King reveals that Hamlet is roughly thirty years of age, based on the years Gertrude and the King have been married: "Full thirty times hath Phoebus' cart gone round... And thirty dozen moons with borrowed sheen about the world have times twelve thirties been since love our hearts and Hymen did our hands unite commutual in most sacred bands" (176-181). Additionally, it is revealed that Hamlet was at a university prior to his father's demise, and had also been courting Ophellia.

In order to fulfill the requirements of his genre, Shakespeare had to present his Hamlet as a full-grown man. The Danish legend takes years to complete, chronicling almost the entire life of Amleth. "Shakespeare avoids that whole problem by modifying this part of the story and relegating it to a period before the play begins" (Hansen 71). Thus, Shakespeare's Hamlet occurs in a matter of weeks. In order to be set on stage, the timing of the original legend needed to be compressed, and Hamlet needed to appear full grown. However, Hamlet does retain vestiges of his predecessor's age; Amleth's delay in acting imposed by his age is present in Hamlet as well. Hamlet's hesitation to avenge his father is a remnant of the timing in the Ur-Hamlet, proving problematic in Hamlet.

Even young, Amleth is fully aware of whom his father's murderer is. Hamlet, however, is not. The only proof he has of the murder, up until Claudius' admission to guilt during prayer, rests on the ghost's speech. Hamlet thus organizes a play, "The Murder of Gonzago," with events similar to those recounted by the ghost. Hamlet describes his reasoning behind the play as such:

Hum, I have heard that guilty creatures sitting at a play have, by the very cunning of the scene, been struck so to the soul that presently they have proclaimed their malefactions. For murder, though it have no tongue, will speak with most miraculous organ. I'll have these players play something like the murder of my father before mine uncle. I'll observe his looks; I'll observe his looks; I'll tent him to the quick. If he do blench, I know my 
course The spirit that I have seen may be a (devil), and the (devil) hath power t' assume a pleasing shape; yea, and perhaps, out of my weakness and my melancholy, as he is very potent with such spirits, abuses me to damn him Ill have grounds more relative than this. The play's the thing wherein I'll catch the conscience of the King.

(II, ii, 617-634)

Thus, the play is introduced in order to prove the validity of the ghost's claims. Horatio is brought in to assist with the matter as well. Hamlet states,

There is a play tonight before the King. One scene of it comes near the circumstance which I have told thee of my father's death. I prithee, when thou seest that act afoot, even with the very comment of thy soul observe my uncle. If his occulted guilt do not itself unkennel in one speech, it is a damned ghost that we have seen, and my imaginations are as foul as Vulcan's stithy. Give him heedful note, for I mine eyes will rivet to his face, and after, we will both our judgments join in censure of his seeming.

(III, ii, 80-92)

The "play within a play" proves successful in validating the ghost's claims. Claudius calls for an end to the play just as Lucianus pours the poison into the Player King's ear. Guildenstern described him "distempered" with "choler," indicating his rage. After witnessing Claudius' reaction to the "play within a play," Hamlet states, "I'll take the ghost's word for a thousand pound" (III, ii, 312-313).

There is no mention of such a play in either Saxo or Belleforest. "The Danish story does not mention poison, sleep or orchard. On the contrary, Belleforest expressly states that the deed was done by bloody violence in the banqueting-hall of the palace, while Amleth's father sat at meat" (Bullough 440). Shakespeare chooses stylistically to hide Claudius' murder. The only way, then, to justify the claims made by the ghost is to have Hamlet test his uncle. The Danish story did not require testing from Amleth to prove who committed the murder of his father because it was already known. Since the crime was committed clandestinely in Shakespeare's version, Hamlet needs a way of verifying the claims made by the ghost. Upon seeing the King's reaction, Hamlet had his confirmation in the truth of the ghost's confession. However, upon confirmation, why was the vengeance still delayed? 
A central action in the Ur-Hamlet involved a voyage to England, imposed on Amleth by Fengi, who "...strongly suspected his stepson of deception and wished to do away with him..." (Hansen 103). Up until this point, Claudius is unaware that his crime is known by Hamlet. While wary of his madness, Claudius does not fear Hamlet. The play then serves as a reason for Claudius to finally associate Hamlet's madness to his crime. In the next act, he states, "I like him not, nor stands it safe with us to let his madness range" (III, iii, 1-2), thus admitting his fear of Hamlet. "The Murder of Gonzago" thus ushers forth this distrust, leading to the attempts on Hamlet's life.

"The Murder of Gonzago" then serves a two-fold purpose. Claudius realizes the danger he faces allowing Hamlet to remain at court, leading to the voyage to England, which played a major role in the Ur-Hamlet. Yes, Claudius did discuss sending him before the dumb-show occurred in Act III, scene ii, but there the voyage was suggested to help Hamlet rid himself of his melancholy. However, the true purpose of the voyage as seen in the Danish legend is to murder the would-be avenger. By utilizing the play within a play, Shakespeare is able to bring forth that element from the Ur-Hamlet. After Claudius realizes Hamlet knows of his offense, he sends him off to his death in England.

Claudius' reaction to the play further proves the ghost's point. This justifies Hamlet's revenge and elevates him from murderer to avenger. "Hamlet (Amleth, Ambales, Amodhi, etc.) in the role of culture hero appears on the local, 'earthly' level as an avenger against the tyrant ruler, whom he succeeds as the lawful and just sovereign" (Sadowski 300). To his court, and to those audience members who doubt the veracity of the ghost's story, no justifiable means for retribution exist up until this point. Claudius' reaction to "The Murder of Gonzago" then justifies Hamlet's spying and attempted murder while Claudius is at prayer in Act III, scene iii. It is then during this scene that Hamlet finally receives confirmation from Claudius of his misdeed. 
Saxo and Belleforest describe three tests by which Hamlet's predecessor proves himself to be wiser than his uncle. Shakespeare utilizes the same tests, but provides a more in depth look at their usage. "What is more to the point, we still have the series of tests, made in fact more complex, and its significance remains basically the same" (Birenbaum 22). Since the tests play a major role in the Ur-Hamlet, Shakespeare needed to employ them in his Hamlet. However, since Hamlet is presented as an adult, and therefore does not need time to mature, the reasons for the tests differ. Amleth undergoes trials in order to allow him to mature and carry out his plan. Similarly, Shakespeare also submits Hamlet to these trials to facilitate his maturation. According to Harvey Birenbaum, "From each encounter, Hamlet emerges even stronger, and he finds himself one step closer to the King himself. As Laertes falls, accusing Claudius, the King and the Prince are ready to meet face-to-face in the mutual death which marks the ultimate failure of the one and the ultimate success of the other" (22). Even though he may be physically ready to avenge his father, like his predecessor, he is not mentally prepared.

Thus, examining the basic characteristics of both stories' titular characters reveals an evolution of sorts. Not only are their names remarkably similar, each undergoes parallel circumstances. Whereas in Hamlet, the three tests may seem to serve no purpose, and add to the issue of Hamlet's delay, comparing the play to the Ur-Hamlet reveals the necessity to have Hamlet submit to and pass these trials.

Shakespeare's interpretation of Hamlet is also reminiscent of the sequence of events present in hero myths. Part of the legend involves a warning to the father against the son. The play within the play serves as that warning. Additionally, after the father receives warning, the son is sentenced to death through a body of water. Similarly, Claudius sends Hamlet afterwards on a sea voyage, intending to have him killed. However, Hamlet is saved by pirates. This also coincides with the hero myth, which grants the hero salvation from a watery death through the intercession of animals or lowborn people (Rank 47). Without delving into the issue of his delay 
or his melancholy, Hamlet already exists as an evolution of not only the Amleth story, but also of the hero myth in general. Taken in isolation, Shakespeare's depiction lends itself to an incomplete portrayal of the character, causing confusion in regards to his actions. Contrasting Hamlet with Amleth, and by extension the characters from the various incarnations of the "Hero as Fool" myth, yields explanations to the many curiosities of his persona.

Examining Claudius also leads to questions left unanswered by Shakespeare. He neglects to delineate his ruling history, and unlike his progenitor, the audience is unaware of his motives up until almost the end of the play. A comparison between Claudius and Fengi, however, illustrates the complexity of the character and provides insight as to why Claudius committed the regicide, beyond the envy made evident in the play. The actions done by Fengi in the Amleth legend are carried over by Claudius. As previously mentioned, both characters usurp the throne by means of fratricide, marry their brothers' wives, and plot against their nephews.

The Danish legend provides a brief ruling history before delving into Amleth's story. Saxo and Belleforest describe the relationship between Fengi and Orvendil as co-rulers: "Rorik put Orvendil and Fengi in charge of defense of Jutland. They succeeded their father Gervendil, who had been jarl of the Jutes" (Hansen 96). Shakespeare provides no such explanation of the ruling relationship in Denmark. Were Claudius and the elder Hamlet joint rulers? If so, then Claudius would be the next in line after his death. However, no such evidence is provided in the text. Claudius does state that Hamlet is “...the most immediate...” (I, ii, 113) to the throne, but provides no explanation as to why Hamlet did not ascend the throne after his father's death.

This is yet another example of an unresolved problem brought to light by examining the Ur-Hamlet. Hamlet, being 30 years of age, could rule. His predecessor is not old enough, and since both his uncle and father ruled jointly, he did not have a claim to the throne as long as his uncle still lived. Shakespeare neglects to offer an explanation for the disparity. However, one can 
assume that based on the Ur-Hamlet, a similar ruling relationship existed in Denmark, therefore making Hamlet ineligible to rule as long as the country's co-ruler still lived.

Another theory surrounding the monarchical history of Hamlet involves Gertrude. In the Ur-Hamlet, the Gertrude character is the sister of the King of Jutland, given to Orvendil as a reward for success on the battle field. With Orvendil dead, the King of Jutland may have declared her ruler. Thus, if King Hamlet and Claudius were not co-rulers then, with the death of King Hamlet, Gertrude may have been eligible to rule. This would provide one reason for her hasty marriage to the usurper. In both Hamlet and the Ur-Hamlet, the marriage occurs immediately preceding the murder. In the Danish legend, Saxo describes the wedding as almost occurring simultaneously to the murder: "For a man who gives in to one crime rushes headlong onto a second, since one goads him to the next" (Hansen 97). In Hamlet, the wedding occurs a month after the wedding. While explaining the state of affairs, Claudius describes the country as one "...[w]ith mirth in funeral and with dirge in marriage" (I, ii, 12). Furthermore, he announces Gertrude as his, “... sometime sister, now... queen, th' imperial jointress to this warlike state” (I, ii, 8-9).

Perhaps the claim to the throne lay with Gertrude, and not King Hamlet, which would explain the urgency that both stories place on her wedding. With that in mind,

“...[I]t is not easy to dispel the impression that their wedding does have something to do with their status as rulers. It is a matter of immediacy... Both Saxo and Belleforest make the point that [Fengi's] first concern after killing his brother was to marry his widow... All of this goes beyond mere coincidence..."

(Aguirre 167-68)

The rushed wedding may have occurred then to cement both Fengi and Claudius' claim to the throne through Geruth and Gertrude.

In the Amleth legend, Fengi's crime is described as one motivated by envy. However, Shakespeare adds depth to Claudius' progenitor, implying that Claudius' envy extended beyond the throne. When describing his acquisitions while in prayer, Claudius mentions both the throne 
and his queen as his offense: “...[S]ince I am still possessed of those effects for which I did the murder: my crown, mine own ambition, and my queen" (III, iii, 40-42). Furthermore, the ghost reveals to Hamlet that Claudius actively pursued his wife, stating, "Ay, that incestuous, that adulterate beast, with witchcraft of his wit, with traitourous gifts- $\mathrm{O}$ wicked wit and gifts, that have the power so to seduce!- won to his shameful lust the will of my most seeming-virtuous queen" (I, iv, 49-52). In Shakespeare's version then, the envy Fengi is described as burning with is expanded to include his brother's wife as well.

But is this seduction an invention of Shakespeare's? While Saxo does not delve into the details of Geruth's seduction Belleforest adds a new layer to the crime, stating that Fengi “...had already had sexual relations with [Geruth] before her husband's death" (Aguirre 167). The haste in marriage may not have been solely political in nature. Taking from Belleforest, Shakespeare may have wanted to imply that, like Fengi and Geruth, Gertrude and Claudius too had an illicit love affair. While not stating so directly, the implications from Claudius' speech as well as his progenitor's actions point to a prior seduction. Like Fengi, Claudius was spurred to commit regicide not only for ambition, but also for lust.

Fengi immediately admits to the murder of his brother, but “...justified his crime by pretending that he had acted from good will and disguised the murder as an act of duty" (Hansen 97). Neither Saxo nor Belleforest mention any feelings of remorse for his crime, and nothing from either translation implies otherwise.

Shakespeare, however, chooses to keep Claudius' crime hidden. Hamlet is made aware of it through his father's ghost. Additionally, in Act III, scene iii, Claudius does admit to his crime while in prayer, stating:

"My offense is rank, it smells to heaven; it hath the primal eldest curse upon 't, a brother's murder... What if this cursed hand were thicker than itself with brother's blood? Is there not rain enough in the sweet heavens to wash it white as snow? Whereto serves mercy but to confront the visage of offense... 'Forgive me my foul murder'? That cannot be, since I am still possessed of those effects for which I did the murder: my 
crown, mine own ambition, and my queen. May one be pardoned and retain the' offense... Try what repentance can. What can it not? Yet what can it, when one cannot repent? O wretched state! O bosom black as death! O limed soul, that, struggling to be free, art more engaged!"

$$
\text { (III, iii, 40-42, 47-51, 56-60, 69-73) }
$$

Unlike his progenitor, Claudius does exhibit remorse for his act. Rather than totally vilify him, Shakespeare chooses to have him admit his crime in prayer. However, his admission proves fruitless as he finds himself unable to pray: "My words fly up, my thoughts remain below; words without thoughts never to heaven go" (III, iii, 102-103). This confession by Claudius may show a disparity at first between the two characters. No similar scene exists in Saxo or Belleforest. Claudius feels guilt for his crime, whereas Fengi does not. Yet, the guilt Claudius feels is not genuine. He does not renounce his throne or his queen, and immediately after, plots to send Hamlet to his death. Because of this, the scene may seem unnecessary.

This change made by Shakespeare is odd, yet makes sense in the context of the play. In the Ur-Hamlet, Fengi's crime is well known. Up until this point in Hamlet, Hamlet lacks concrete evidence to implicate Claudius as his father's murderer. He was told of the crime by a ghost, but is unsure of the ghost's legitimacy. While Barnardo believes him to be the elder Hamlet, stating, "It is the same figure like the King that's dead" (I, i, 48), Hamlet cannot be sure. Additionally, “The Murder of Gonzago,” while leading to Claudius' abrupt departure, only hinted at his guilt. It is not until Claudius' prayer scene that both Hamlet and the audience know for certain of Claudius' misdeeds.

Shakespeare creates the perfect scenario for Hamlet to prove the truth of the ghost's claims that both illustrates Claudius' insincerity and prevents Hamlet from enacting his revenge. The Ur-Hamlet describes Fengi's crime, but Amleth is prevented from acting due to his age and circumstances. Shakespeare waits until Claudius is at prayer to reveal the fratricide. Hamlet cannot avenge his father's death at that moment because of the circumstances, and unbeknownst 
to him, Claudius' prayers prove futile. It is the ideal scene to both reveal the fratricide as well as maintain Claudius' guilt, reminiscent of Fengi's.

Amleth is put through three trials, of which he all passes, devised by Fengi to prove his supposed madness. As mentioned earlier, with the completion of each, Amleth grew and moved towards his retribution. However, the tests also juxtaposed both the protagonist and antagonist, pitting one against the other. While Amleth matured, Fengi remained static, resorting to more desperate means to prove Amleth's false lunacy and finally to rid himself of his nephew.

Fengi and his cohorts first utilize a woman to attempt to coerce Amleth into revealing his lunacy to be false:

"They thought that the best way to expose his cunning was to bring him together with a beautiful woman in some secluded place where she could tempt him with pleasures of love; for by their very nature emotions turn into passion so quickly that they cannot be skillfully concealed, the impulse being too powerful to be checked by cleverness; if, then, he was only pretending to be witless, he would immediately give in to pleasure when occasion was offered"

(Hansen 99)

Amleth of course passed the test, which led Fengi to administer a second test, this time pitting

Amleth's mother against him:

"Amleth was to be enclosed alone with his mother in her bedroom, but before that it should be arranged for a man to station himself, unknowns to the two of them, in a dark part of the room to overhear carefully what they should talk about; for if her son was at all sane, he would not hesitate to speak out to his own mother and would not be afraid to confide in the very woman who gave him birth."

(Hansen 101)

Amleth, suspecting treachery, foils Fengi once again, murdering one of his advisors in the process.

After the second test, "Fengi... strongly suspected his stepson of deception and wished to do away with him..." (Hansen 103). According to Saxo, "He decided to have the King of Britain kill him so that he himself could pretend to be innocent, another man doing the deed. In his desire to conceal his own cruelty, he chose to soil a friend rather than to bring dishonor upon himself" 
(Hansen 103). Thus, the third trial served to illustrate Fengi's cowardice. Rather than murder Amleth, he chooses to send him to England, bearing a letter ordering his death.

Claudius tests Hamlet similarly, with matching results. Like in the Danish legend, Hamlet's first test pits his supposed insanity against lustful temptation. Polonius decides to investigate where Hamlet's lunacy stems through his daughter, Ophelia: “At such a time, I'll loose my daughter to him. Be you and I behind an arras then. Mark the encounter. If he love her not, and be not from his reason fall'n thereon, let me be no assistant for a state, but keep a farm and carters" (II, ii, 176-181). Like Amleth, Hamlet sees through the trap and avoids detection.

After passing that test, Claudius sets up a scheme to spy on Hamlet in his mother's closet. Polonius states, “...Let his queen-mother all alone entreat him to show his grief. Let her be round with him; and I'll be placed, so please you, in the ear of all their conference. If she find him not, to England send him, or confine him where your wisdom best shall think" (III, ii, 196-201). That test also yields the same result as the Danish legend. Polonius is murdered, and Claudius fails yet again to ascertain the validity of Hamlet's madness.

Realizing Hamlet may pose a threat to himself, Claudius then unleashes his final trial. He decides to send Hamlet off to England with a sealed letter ordering “...the present death of Hamlet" (IV, iv, 73). Unable to do the deed himself, he, like Fengi, seeks out a third party. Both Claudius and Fengi are unable to themselves murder Hamlet, and thus order him to be murdered, in England. Neither wishes to soil their own hands with the death of their nephew, choosing to avoid the consequences that may arise if that occurs. Sending Hamlet and Amleth to England frees Claudius and Fengi from the crime, ensuring that it remain unknown in their own kingdoms. As his progenitor did before him, Hamlet also sees through this trap, returning from the sea ready to face Claudius.

Thus, Shakespeare borrowed heavily from the Amleth saga for his depiction of the villain in his play, Claudius. Both Fengi and Claudius share the same motives and desires, implementing 
similar methods for accomplishing their crimes. Fengi lends himself wholly to the Hamlet text, and Claudius becomes a direct representation of him. Moreover, Claudius becomes an almost identical copy. Claudius' persona alone is enough to substantiate the Danish legend's claim as the Ur-Hamlet.

The connection between Ophelia and her predecessor is not as evident. In the original legend, she exists as a means of temptation for Amleth, and he is left alone with her. Saxo describes the scene as follows:

"Therefore, if his lethargy were feigned, he would seize the opportunity, and yield straightway to violent delights... He was then left alone and it was arranged that he should meet the woman in a dark place in the forest, as if by chance... Amleth, perceiving the plot, took the girl off to a secluded spot, where he had his will with her. He urged her to tell no one, and his wish was granted, for they were intimate, having been reared together in childhood. Upon his return, he announced that he had ravished her, and when asked where he had done it, he replied in terms of such folly that all were deceived. The maiden, however, denied Amleth's allegation, and she was believed, because no one had been a witness."

(Lawrence, "Ophelia” 410-411)

There is no further mention of her in the story.

Belleforest treats the character similarly; however, in his version, she is denied the few

words spoken in Saxo's account. William Lawrence describes this change, stating,

"Belleforest did not individualize the girl or even give her a name ... The girl's revelation of the plot was retained; also her friendship with the hero since childhood, and her declaration that Amleth had not violated her, though he affirmed the contrary... Finally it should be observed that the episode is only a very small part of Belleforest's long story, and that the girl never comes into the tale again."

(“Ophelia” 412)

Like Saxo, Belleforest does not go into detail as to the fate of this character. After her role in the trial, she fades into oblivion.

The Ur-Hamlet mentions two other female characters who serve as Amleth's love interests: the King of England's daughter and Queen Herminthrud of Scotland. While in England, Amleth weds the King of England's daughter and later on has a child with her. Like his fostersister, she remains nameless. Since Hamlet does not complete his voyage to England, no mention 
of her is made. However, aspects of her persona come through Ophelia. His other conquest, Herminthrud, is introduced to the story after Amleth avenges the death of his father. He marries her as well. Neither exists as individual characters in Hamlet; yet, vestiges of their personas can be seen through Ophelia.

Herminthrud comes into the legend after the events surrounding the revenge have been completed. While no explicit mention of her exists in Hamlet, Shakespeare incorporates elements from her character into his version. The King of England, desiring to be rid of Amleth, sends him to Herminthrud under false pretenses:

"Because his wife had recently died of illness, he bade Amleth undertake a mission to arrange a new marriage for him... He declared that there was a woman reigning in Scotland whom he desired very much to marry. But the king knew that she not only wanted to remain a virgin but was a cruel and arrogant woman who hated her suitors and always put her would-be lovers to death, so that every one of those many men had paid for his suit with his life"

(Hansen 112-13)

However, Herminthrud, after spying on Amleth and learning of his acts against Fengi, decides to take him as her husband rather than the King of England (Hansen 113). Amleth proceeds with the marriage, even though he is already wed to the King of England's daughter.

The King of England's daughter, upon hearing the news, reacts well: "Though she complained that he had slighted her by replacing her with a mistress, she said that it was not right for her to put her hatred of his mistress before her love of her husband... For as a pledge of their marriage she had their son..." (Hansen 115). Furthermore, she warns Amleth of a plot against his life by her father: "No crisis will quench my passion for you; no envy will put an end to my love or stop me from revealing to you the evil plot against you and the treachery I have discovered" (Hansen 115). She is not mentioned in the story again.

Herminthrud does play a larger role in the legend, post-revenge. Amleth, concerned about the fate of Herminthrud, expresses for her his desire to find her a second husband in case he perishes in battle. Herminthrud responds, stating that "... she had the courage of a man and 
promised that even on the field she would not desert him, saying that any woman who was afraid to join her husband in death was detestable" (Hansen 117). However, after Amleth's death, she does break her vow, “... [yielding] herself to be the victor's spoil and [sharing] his bed” (Hansen 117). This triggers a tirade against women by Saxo, who refers to the gender as "slaves of pleasure" and berates them for leaping "...headfirst and gaping in their continual longing for something new... [forgetting] the old" (Hansen 117).

Therefore, Shakespeare had three female characters to draw from when creating Ophelia, and Ophelia thus becomes an amalgamation of her three predecessors. She serves as one of Hamlet's tests, but is also his previous lover. Additionally, she remains true to him even after he murders her father. Furthermore, the disillusionment and disappointment expressed by both Saxo and Belleforest at Herminthrud's betrayal is voiced through Hamlet's treatment of her. "In one sense, her character is wholly the creation of Shakespeare. All the finer and subtler touches must be his. The girl who foreshadows her in Belleforest is hardly individualized at all, and it is impossible to believe, after reading The Spanish Tragedy that Kyd could have drawn the Ophelia that we know" (Lawrence, “Ophelia” 409). Through Ophelia, evidence of the Danish legend's legitimacy as the Ur-Hamlet is exposed.

"Shakespeare gives us very little information from which to imagine a past for Ophelia. She appears in only five of the play's twenty scenes; the pre-play course of her love story with Hamlet is known only by a few ambiguous flashbacks. Her tragedy is subordinated in the play..." (Showalter 283). Since Shakespeare provides no details regarding her, the audience is left to speculate upon her background. It is possible that since her father is a Lord of the court, she may have known Hamlet since childhood.

Her main role in Hamlet is to serve as a means for unveiling the cause of Hamlet's lunacy in the first trial. In Act III, scene I, Claudius describes her purpose, stating, "For we have closely sent for Hamlet hither, that he, as 'twere by accident, may here affront Ophelia. Her father and 
myself (lawful espials) (will) so bestow ourselves that, seeing unseen, we may of their encounter frankly judge and gather by him, as he is behaved, if ' $t$ be th' affliction of his love or no that thus he suffers for" (32-40). Even her actions are dictated by Polonius, who ventures as far as to command her on where to stand and how to act: "Ophelia, walk you here... Read on this book, that show of such an exercise may color your (loneliness)" (47-52). She follows their commands without question, and never informs Hamlet of her role in the plot. According to William Lawrence, "Timidity and passivity are part of her nature," ("Ophelia" 409) which would explain her omission as well as her reluctance to warn Hamlet.

But why would Hamlet choose to launch a verbal assault against one so timid? In the original legend, no such attack on the foster-sister exists. While this appears confusing, juxtaposing Ophelia with Amleth's three female companions provides an explanation. The attack on Ophelia's character by Hamlet is brought forth by her predecessor's actions. Shakespeare's play ends after the vengeance is enacted. However, in order to add depth to Ophelia, he utilizes characteristics from female characters who are introduced after the fact, one of whom betrayed Amleth upon his death. Ophelia then not only serves as a part of Hamlet's first trial, she also comes to represent the eventual betrayal Saxo believed all women to be capable of. In Chapter 5, the issue of the tirade Hamlet launches against her in regards to her gender's inability to remain faithful is addressed. Again, this is an echo of Saxo's warning to all men upon revealing the betrayal of Herminthrud. Shakespeare could have had Hamlet proceed as his predecessor did, escorting Ophelia to a hidden location and revealing his true nature. However, he chose not to. Instead, the moment is utilized to voice the sentiments expressed by Saxo at the end of Amleth's story.

Hamlet continues his verbal attack on Ophelia during "The Murder of Gonzago." However, this time, instead of speaking of her gender's disloyalty, he makes crude comments at her expense: 
Hamlet: lady, shall I lie in your lap?

Ophelia: No, my lord.

(Hamlet: I mean, my head upon your lap?

Ophelia: Ay, my lord.)

Hamlet: Do you think I meant country matters?

Ophelia: I think nothing, my lord.

Hamlet: That's a fair though to lie between maids' legs.

Ophelia: What is, my lord?

Hamlet: Nothing.

(III, ii, 119-128)

While no longer violently berating her, Hamlet continues his abuse. "In Elizabethan slang, 'nothing' was a term for the female genitalia... To Hamlet, then, 'nothing' is what lies between maids' legs..." (Showalter 284). Additionally, “country matters" was a term for sexual intercourse. This scene, then, portrays the sexual tension present in both characters. Hamlet is obviously coming on to Ophelia; whether she welcomes his comments or not is unknown.

These words, coming from the same character who previously denounced Ophelia's gender, seem odd. Why then, does Shakespeare make such a drastic change? Ophelia comes to represent an amalgamation of Amleth's female companions. Hamlet accosts her verbally as Amleth would have accosted Herminthrud. Similarly, he provokes her sexually, reflecting Amleth's desire for his foster-sister. Saxo and Belleforest both describe how Amleth takes his foster-sister "...in his arms... [bringing] her to a distant and nearly inaccessible bog where he could more safely do what he wished" (Hansen 100). Shakespeare took that encounter, altering it for his own purposes. Thus, the abrupt change in Hamlet's attitude, believed to be a sign of his lunacy, can be explained by Ophelia's shifting role in the play.

Rather than the carnal meeting shared by Amleth and his foster-sister, Hamlet and Ophelia share erotic puns. "A hero needs a lady love, and the only possible one in Belleforest was the girl of this episode. The two wives, in England and Scotland, were clearly out of the picture. A scene of carnal allurement or actual seduction was unsuited to the stage, and the old idea that Amleth's yielding would prove him sane too absurd to be retained" (Lawrence, "Ophelia" 413). 
Thus, in that one act, Ophelia comes to embody two of the Danish characters. She reflects Amleth's foster sister in her acquiescence to be used as a tool against him, and as a vehicle for the sexuality presented in the earlier legend. At the same time, she also serves as a remnant of Herminthrud's betrayal.

Eventually, housing three different personas and enduring mistreatment from Hamlet, coupled with the death of her father, leads to Ophelia's madness. None of her predecessors experience this; her madness is wholly an invention of Shakespeare's. Why then does Shakespeare force this upon her? One explanation lies in her predecessors. First of all, Ophelia becomes a vessel, housing the personas of Amleth's foster-sister, first wife, and Herminthrud. Hamlet's actions against her reflect this, and the disparity in treatment from scene to scene could have led to her demise.

Additionally, all three of her progenitors successfully consummate their relationship with Amleth; Ophelia does not. He has a sexual relationship with his foster sister and marries both the King of England's daughter and Herminthrud. Ophelia is unable to do either. Her courtship is terminated, and a sexual history between the two is never confirmed outright. According to Lacan, "I have said before that hysteria is characterized by the function of an unsatisfied desire and obsession by the function of an impossible desire" (17). Ophelia's unsatisfied desires stem from her inability to consummate her relationship with Hamlet, as her predecessors did. Additionally, her appearance on stage, coupled with flowers, is also striking, yet further serves to show the tumult present within her due to the unfulfilled sexual requirements. . Ophelia's insanity can be seen as a direct result of her characterization.

During her mad rant, Ophelia sings of Hamlet and Polonius interchangeably. Nowhere in her song does Ophelia accuse Hamlet of murdering her father. Additionally, her song speaks of true love, rather than betrayal. Polonius' murder at the hands of Hamlet was not kept secret; therefore, she must have known the role her former lover played. Even with this knowledge, in 
her madness she continues to stay true to him over familiar bonds. This is reminiscent of the reception Amleth receives by the King of England's daughter. Knowing that he took another wife, and betrayed her, she continues to love him. She states, "No crisis will quench my passion for you; no envy will put an end to my love..." (Hansen 115). Ophelia, betrayed by Hamlet as well, echoes Amleth's first wife's devotion.

Ophelia's madness is presented to the audience through Gertrude, who describes her condition in detail:

"She speaks much of her father, says she hears there's tricks I' th' word, and hems, and beats her heart. Spurns enviously at straws, speaks things in doubt that carry but half sense. Her speech is nothing, yet the unshaped use of it doth move the hearers to collection. They (aim) at it and botch the words up fit to their own thoughts; which, as her winks and nods and gestures yield them, indeed would make one think there might be though, though nothing sure, yet much unhappily"

$(\mathrm{IV}, \mathrm{v}, 5-17)$

Again, Shakespeare employs the usage of the word "nothing," representing the absence of substance. "Ophelia's speech thus represents the horror of having nothing to say in the public terms defined by the court. Deprived of thought, sexuality, and language, Ophelia's story becomes the story of O- the zero, the empty circle or mystery of feminine difference..." (Showalter 284). Ophelia's madness can also then be said to stem from the completion of her purpose in Hamlet. She brings to life all three characters from the Ur-Hamlet: the foster-sister's test, the King of England's daughter's faithfulness, and the yielding of Herminthrud. Ophelia acts as a conduit for her three predecessors, enduring the insults flung at her by Hamlet because her predecessor wronged his.

Ophelia exists as a character made up of pieces which fail to equal a whole. Her predecessors consisted of minor characters whose input in the legend was vital to its completion. However, they were minor characters, appearing on one page and fading off into obscurity shortly after. Both Saxo and Belleforest do not relate any further news of the King of England's daughter, besides her acceptance of her husband's marriage and continued support of him. Amleth's foster- 
sister is not mentioned after the test scene. Herminthrud, who appears after the act of vengeance is complete, only exists to serve as an example of female impiety.

No description of these female characters' deaths exist in the Danish legend; yet

Shakespeare decides to describe Ophelia's final moment in detail:

"Therewith fantastic garlands did she make of crowflowers, nettles, daisies, and long purples... There on the pendan boughs her coronet weeds clamb'ring to hang, an envious silver broke, when down her weedy tropies and herself fell in the weeping brook. Her clothes spread wide, and mermaid-like awhile they bore her up, which time she chanted snatches of old lauds, as one incapable of her own distress or like a creature native and endued unto that element. But long it could not be till that her garments, heavy with their drink, pulled the poor wretch from her melodious lay to muddy death"

(IV, vii, 192-209)

Her death alludes to her eventual return to nature. Shakespeare's decision to depict her death in such a matter reflects his usage of her. In death, Ophelia returns to the nothing from which she came. As a character composed of parts, once those parts have fulfilled their purpose, Ophelia is left with essentially nothing.

Ophelia's character is unique. Rather than a direct reflection of one character, Shakespeare utilizes her to reflect each female character Amleth comes in contact with. This leads to the disparity that eventually causes her downfall. She is bound by her predecessors to act in a certain manner, but is unable to. She receives harsh treatment from Hamlet, and is used as a pawn by her father and Claudius. While the other characters are allowed a voice, she is not. Shakespeare's utilization of Ophelia thus illustrates the relationship between Hamlet and the UrHamlet. The various roles she plays, strange when looked upon in isolation, are explained when compared to the earlier story. Because of this, she proves to be one of Shakespeare's most complex creations.

Hamlet, Claudius, and Ophelia thus represent Shakespeare's direct borrowing from the Ur-Hamlet. While other characters in the play also serve as reflections, none elucidate the Amleth 
legend's claim as clearly as these. Each character becomes an evolved form of the original; the character disparities that plagued Shakespeare's work can be explained by examining the original.

\section{CHAPTER VI}

\section{ANSWERED QUESTIONS}

Some aspects of Shakespeare's Hamlet seem an ill fit with the play itself. For instance, why is there a need for a ghost whose authenticity is questioned? Why would Hamlet feign madness upon hearing the ghost's claims and, upon receiving verification of the act, delay in action? Furthermore, why does Shakespeare send Hamlet on a voyage to England, only to have him return within the same Act? "In several ways the play is puzzling, and disquieting as is none of the others. Of all the plays it is the longest and is possibly the- one on which Shakespeare spent most pains; and yet he has left in it superfluous and inconsistent scenes which even hasty revision should have noticed" (Williamson 91). Examining the play itself yields no explanations. Additionally, the other supposed candidates for the Ur-Hamlet, The Spanish Tragedy and Antonio's Revenge also fail to produce a plausible cause for these curious elements.

An archetypal comparison between the Amleth legend and Hamlet provides cause and explanation for these inclusions. Again, the legend's ability to do so attests to its claim as the $U r$ Hamlet and reveals the extent of borrowing by Shakespeare. However, in his borrowing, he left out what justified those particular characteristics, making it very difficult to understand them in a new context. Examining the Danish legend allows one to further comprehend the implications these aspects have on the plot and characters themselves in Hamlet.

A major point in Hamlet is Hamlet's supposed madness, which has roots in "The Hero as Fool" story. As previously explained, the tale involves a young hero feigning madness to protect himself. The guise is assumed until the hero is ready to challenge his nemesis. Amleth utilizes this method to protect himself against Fengi. Hamlet too adopts lunacy upon hearing of his father's murder. This and other “...important facets of Hamlet's character have probable basis in 
Saxo and Belleforest..." (Stabler, "Melancholy" 207). According to Lacan, "However superficial this characteristic may seem to you, it's still the thing that Shakespeare seized on for his Hamlet. He chose the story of a hero who is forced to feign madness in order to follow the winding paths that lead him to the completion of his act" (20). However, the feigned madness in Hamlet remains unclear and inconsistent. Hamlet rants in one scene, and returns to normal in another. This shift in personality seems odd. Additionally, the characteristic does seem superficial, and Shakespeare does not elaborate as to why Hamlet adopts it.

In the Danish legend, it is clear that Amleth must feign madness in order to avoid persecution and death at the hands of his uncle: "Amleth saw this and feared that he might make his uncle suspicious if he behaved intelligently. So he feigned madness and pretended that his mind had been damaged. With this cunning he not only concealed his cleverness but also guarded his life" (Hansen 98). Amleth is young and outnumbered. Fengi seems to have several supporters who agree with the regicide. "His initial response to his uncle is therefore defensive rather than offensive. By his guise as a fool, made credible by the sudden death and replacement of his father, Amleth means to suggest that he is incapable of exacting vengeance" (Hansen 124-25). As discussed in Chapter V, Fengi puts Amleth through a series of trials to determine the legitimacy of his lunacy, which he passes. By passing each, Amleth is able not only to amass time for his revenge and growth, but also exacerbate his simulated condition.

Hamlet also decides to feign madness after hearing the Ghost's claims in Act I, scene v. After asking Horatio and Marcellus to swear never to reveal the events of that night, he goes on to describe how they must also never provide reason for the "strange or odd" behaviors he may display or any "antic dispositions" he may put on. However, he does not provide a reason for behaving so. As with Amleth, part of the play involves trials set in place by Claudius and Polonius, reminiscent of those in the Danish legend, which Hamlet undergoes in order to determine first a cause and then the legitimacy of his behaviors. "Thus arises that peculiar and 
dexterous struggle in which Hamlet seeks to conceal his thoughts and purposes, and the King tries to discover them" (Snider 80).

The reason for Hamlet's mental disguise is puzzling. Hamlet never states that he means to pretend in order to ensure his preservation; no reason at all is provided. Whereas Amleth is presented as a child, Hamlet is a full grown adult, capable of defending himself if needed. Furthermore, Horatio and Marcellus demonstrate their loyalty to him through their oath in Act I. Therefore, the madness must certainly not be interpreted as a defense mechanism for Hamlet.

He could have decided to feign madness in order to remain at court near Claudius, waiting for him to grow complacent in order to exact vengeance as was the case in the $U r$ Hamlet. If that were so, it would mean an acceptance of the Ghost's claims as truth, proving "The Murder of Gonzago" unnecessary. Additionally, Hamlet would have had to maintain the foolish act throughout the play, up until the moment of vengeance, but he does not. No reason behind Hamlet's supposed madness can be found in the text itself.

Some argue that the madness is a borrowed motif from The Spanish Tragedy. However, in that play, the madness is not feigned. The only explanation that can be gathered for Hamlet's ill-planned disguise lies in the Amleth story. As previously discussed, Shakespeare borrowed numerous elements for his characters from the earlier legend, one of which being Amleth's madness. While in Amleth's case the madness blends with the story, in Hamlet, it does not. However, Hamlet needed to assume that particular disguise; his inane yet witty dialogue as well as the various traps set for him would have no meaning if he were not pretending. Hamlet's madness is then a curious example of an idea Shakespeare borrowed which did not blend successfully with the format of his work. Examining Hamlet's madness compared to Amleth's reveals the complex nature of the act.

Amleth is described by Saxo as fully donning the role of the lunatic in both appearance and actions: "Every day he sat on the ground at his mother's hearth, unkempt and listless, and 
tossed dirt upon himself. With his soiled face and his skin smeared with putrid slime, he looked like a grotesque madman... Whenever he spoke, he spoke like a fool, and whatever he did he did with utter foolishness" (Hansen 98).

Being written as a play, Shakespeare's work does not have Hamlet's appearance explicitly stated. In order to convey this to his audience, Shakespeare has Hamlet appear to Ophelia in her quarters. She describes the event to her father, stating:

"[A]s I was sewing in my closet, Lord Hamlet, with his doublet all unbraced, no hat upon his head, his stockings fouled, ungartered, and down-gyved to his ankle, pale as his shirt, his knees knocking each other, and with a look so piteous in purport as if he had been loosed out of hell to speak of horrors- he comes before me"

(II, i, 87-94)

She goes on to express confusion as to his purpose in her quarters:

"He took me by the wrist and held me hard. Then goes he to the length of all his arm, and, with his other hand thus o'er his brow, he falls to such perusal of my face as he would draw it. Long stayed he so. At least, a little shaking of mine arm, and thrice his head thus waving up and down, he raised a sigh so piteous and profound as it did seem to shatter all his bulk and $\mathrm{d}$ his being. That done, he lets me go, and, with his head over his shoulder turned, he seemed to find his way without his eyes..."

(II, i, 99-110)

Again, Hamlet fails to explain the reason behind his appearance in Ophelia's room. He may have appeared to her in order to bid her farewell and in doing so, appeared thusly. Yet, why take his leave of her at all when in the previous Act he swears to avenge his father at all costs?

Furthermore, why remain silent? While unclear on its own, this scene serves as a means for Shakespeare to expose Hamlet's appearance to the audience as well as to the other characters. Shakespeare needed a means by which to show Hamlet's madness. Given that the work is in play form, having Hamlet appear to Ophelia in such a state allows exposition to the audience and characters in the story.

In both Hamlet and Amleth's story, the main character is tested in order to determine the legitimacy of his ruse. As discussed in Chapter V, the Danish legend describes the trials as a means of proving Amleth's lunacy false. Before his first test, Amleth is warned of the trap by a 
foster brother, who joins Fengi's men in order to protect him. However, the ploy against him was “...plain enough to Amleth himself” (Hansen 99), and he proceeds to act foolish in the presence of Fengi's men. He mounts his horse backwards, intending to ride it in that manner. "With this ingenuity he frustrated his uncle's plan and foiled his trap" (Hansen 99). This test also illustrates Amleth's wit and ability to “...[mix] truth and cleverness in such a way that [one] could not call his words false, although they did not betray their real meaning" (Hansen 99).

In his speech, he is able to criticize his uncle while maintaining his madness. When his companions describe a wolf as a horse, Amleth states, "In Fengi's stable there are too few of this kind fighting" (Hansen 99), thus criticizing his uncle's wealth. Amleth is also able to combine inane speech with truth. Saxo describes this skill further into the first trial: "As he was passing along a beach and came upon the rudder of a wrecked ship, his companions said they had found a huge knife. 'Yes,' he said, 'it is suitable for cutting a huge ham' by which he really meant the sea, since its vastness matched the size of the rudder" (Hansen 99). In this way, Amleth is able to state the truth of his acts while maintaining the ruse.

Amleth suspects a second trap in his mother's chamber, suggested to Fengi by one of his friends. This friend is described as one "... who had more confidence than he had judgement" (Hansen 101). The friend decides to hide himself in Geruth's chamber, believing that Amleth would reveal his true self to his mother. However, Amleth suspects treachery and acts accordingly:

"Fearing that someone might secretly eavesdrop, he resorted at first to his usual silliness, crowing like a noisy rooster and beating his arms together as though were flapping wings. Getting up on the straw, he began to leap around to find out whether anything lay lurking there. When he perceived a lump beneath his feet, he clove the spot with his sword, stabbing the man who lay underneath, dragged him out of his hiding place, and slew him. He cut up the body, cooked the pieces in boiling water, and dumped them through the hole of the outhouse for the swine to eat, strewing the putrid refuse with the wretch's limbs"

(Hansen 101-102) 
Questioned about the location of the spy, Amleth “...reported that the man had gone to the outhouse and fallen through the hole; overwhelmed by all the filth, he was devoured by the swine that go around there" (Hansen 102). Thus Amleth successfully passes another trial, continuing to maintain his disguise.

The final test sends Amleth to Britain, where Fengi hopes to have him killed. While not necessarily a test of his claims, failing to see through the trap would have resulted in Amleth's death. Fengi sends Amleth with two of his housecarls, carrying a letter carved on wood with instructions for the King of Britain to execute the young man who was sent to him. However, Amleth, while the two sleep, changes the letter to instead have the housecarls killed. Arriving in Britain, the messengers hand the King the letter containing their death sentence. Reading it, the King orders the housecarls hung the next day (Hansen 103, 105). After spending a year in Britain, Amleth returns to Jutland. Once again feigning madness, he finally carries out his vengeance.

Thus, in the Amleth legend, the tests serve as a means of both vilifying Fengi and highlighting Amleth's wit. He maintains the charade throughout, only ceasing his assumed madness while in Britain, but reprising the disguise upon his return. The madness act is successful then in protecting Amleth until he is old enough to avenge his father.

Unlike his progenitor, Hamlet's act of madness is not outright questioned until the end of the first test. At first, both Claudius and Fengi seek to determine its source rather than focus on its legitimacy. In Shakespeare's depiction, no reason exists for the characters to doubt Hamlet. Fengi remains wary because his crime was known by all. Since Claudius' is unaware that Hamlet suspects him of foul play, he has no reason to doubt Hamlet at first. Doubt does exist, but not as blatant as with Amleth. While administered for different reasons, the tests do produce the same results.

Like Amleth, Hamlet proves himself verbally apt through these trials. He is able to launch witty insults at others while still casting doubt over his sanity. According to Ann Barton, 
"Hamlet ... seems to be the only one of Shakespeare's tragic protagonists ... who possesses - and demonstrates - a sense of humor. Like the witty characters of the comedies, he likes to play games with language, to parody other characters' verbal styles, and he has a predilection for puns, bawdy double entendres, and sophisticated badinage..."

(Draudt 71)

Hamlet, like Amleth, utilizes inane comments as vessels for witty retorts as well as unveiling hidden truths. This is evident in Act II, scene ii, when questioned by Polonius prior to his encounter with Ophelia.

In this scene, Polonius decides to use his daughter as a means of determining the source for Hamlet's madness. Believing it to be related to her, he decides to eaves drop on their conversation, but not before embarking on his own conversation with Hamlet. At first, Hamlet refers to him as a "fishmonger" (189). While scholars vary on the word's meaning, some believe it to refer to a proveyor of prostitutes. If that is so, then Hamlet is insinuating that Polonius uses his daughter for political favor (Hassel 617). Polonius does not catch the meaning, leading him to believe Hamlet as "far gone" (206).

As the dialogue continues, Hamlet's contempt for Polonius becomes more evident. When asked to describe the contents of the book he is reading, Hamlet states,

"Slanders, sir; for the satirical rogue says here that old men have gray beards, that their faces are wrinkled, their eyes purging thick amber and plum-tree gum, and that they have a plentiful lack of wit, together with most weak hams; all which, sir, though I most powerfully and potentially believe, yet I hold it not honesty to have it thus set down; for yourself, sir, shall grow old as I am, if, like a crab, you could go backward."

(214-222)

Polonius fails to realize that Hamlet is insulting him. He goes on to describe Polonius as "...a great baby... not yet out of his swaddling clouts" (406-407). Polonius continues to misunderstand Hamlet's true meaning, believing his words to be those of a man driven mad by love, failing to see the clever insults flung at him during Hamlet's speech.

Both Amleth and Hamlet then are able to mask their true intentions through inane comments. However, whereas Amleth continues the charade throughout the first and second test, 
Hamlet does not. Not every character is subjected to Hamlet's clever insults. For example, at first, he treats Rosencratz and Guildenstern pleasantly. Only when he realizes that they have been sent by his uncle does he resume his guise. In an aside, he states, "Nay, then, I have an eye of you" (II, ii, 313), followed by a description of his recent loss of mirth. He even blatantly tells both of them that his madness comes and goes: "I am but mad north-norht-west. When the wind is southerly, I know a hawk from a handsaw" (II, ii, 402-403).

Why the discrepancy? It would have been more plausible for Hamlet to remain under the insane guise, substantiating his claim. Yet, Shakespeare chooses to depict his Hamlet as wavering between the two. Looking at the Ur-Hamlet provides an answer. In the Danish legend, Polonius was in fact multiple characters, all of whom supported his uncle. In each trial, Amleth is surrounded by them, only dropping the façade when alone with his foster-sister, and then while in Britain. When the charade is halted, Amleth is able to prove his wit is true. Shakespeare most likely wanted to imbue his Hamlet with the same capacity for wit. Therefore, he provided Hamlet with the same barbs to utilize against his uncle's supporters. Unlike the Danish legend, in Hamlet Polonius, and later Rosencratz and Guildenstern, are the only characters Hamlet verbally spars with. Thus, in both Saxo and Shakespeare, the main characters continue the ruse with the supporters of their uncles. However, Hamlet is faced with only three, allowing him the freedom to speak somewhat normally with the other characters.

Believing his madness to be genuine and related to his daughter, Polonius arranges for Ophelia to encounter Hamlet while alone. He also plots to hide with Claudius while Hamlet and Ophelia converse. Hamlet utilizes the conversation to insult Ophelia as well as to deny ever loving her. Hearing his remarks, Claudius comes to two conclusions. First of all, he realizes that Ophelia is not the source for Hamlet's madness. Additionally, he begins to suspect Hamlet of deceit: "Love? His affections do not that way tend; nor what he spake, though it lacked form a 
little, was not like madness. There's something in his soul o'er which his melancholy sits on brood..." (III, i, 176-179).

In both Saxo and Shakespeare, women who once played an important role in the lives of Amleth and Hamlet appear as foils to their ruse. This first trial tested both characters' resolve against sexual temptation, an apparent surefire means of detecting any sort of deception of sanity. However, whereas Amleth and his foster sister hide from Fengi's men in order to freely converse and copulate, Hamlet and Ophelia do not. He maintains the charade, and as with Polonius, proceeds to eloquently insult her (III, i, 113-162).

Some may argue that Ophelia, being timid and submissive, did not follow in her predecessor's footsteps by assisting Hamlet because of her obedience to her father. However, examining her statements after her father's death prove otherwise. Moreover, after Hamlet leaves, she states, “O, what a noble mind is here o'erthrown! The courtier's, soldier's, scholar's eye, tongue, sword... and rose of the fair state, the glass of fashion and the mold of form, th' observed of all observers, quite, quite down!" (III, i, 163-168), indicating her love for Hamlet as well as her shock in regards to his words. Why would Shakespeare's version end the encounter so negatively? Unfortunately for Ophelia, "[a] scene of carnal allurement or actual seduction was unsuited to the stage, and the old idea that Amleth's yielding would prove him sane too absurd to be retained" (Lawrence 413). Shakespeare had to alter the ending of this encounter to fit the stage. This alteration provides one reason for Hamlet's gross mistreatment of Ophelia.

Shakespeare continues to follow the sequence of events outlined in the Ur-Hamlet. As with Amleth's second trial, Hamlet's trial takes place in his mother's chamber and involves the death of Polonius, who attempted to eavesdrop on the encounter in hopes of learning more of Hamlet's madness. Hamlet kills Polonius by thrusting a rapier through an arras (III, iv, 28-30). After completing the harangue towards his mother, he leaves, dragging the body behind him (III, 
iv, 241). When questioned upon the location of the body, Hamlet remains elusive, providing answers reflecting his supposed lunacy:

King: Now Hamlet, where's Polonius?

Hamlet: At supper.

King: At supper where?

Hamlet: Not where he eats, but where he is eaten. A certain convocation of politic worms are e'en at him. Your worm is your only emperor for diet...

King: Where is Polonius?

Hamlet: In heaven. Send thither to see. If your messenger find him not there, seek him i' th' other place yourself. But if indeed, you find him not within this month, you shall nose him as you go up the stairs into the lobby.

(IV, iii, 19-24, 36-41)

Hamlet here also utilizes inane comments to mask the truth of his actions. "We all know that some of the crudities of the earlier Amleth still cling to the princely figure of Elsinore, as when he appears strangely callous about the death of Polonius, 'lugging the guts' into the neighbor room, and telling the King that he may nose the body as he goes up the stairs" (Lawrence, "SeaVoyage" 50). In addition to the crudities, however, Amleth's ability to play with words is also present in Hamlet in this scene.

Additionally, the outcome of this event matches that of the Danish legend. However, Hamlet's predecessor is able to avoid blame for the murder. Why then does Shakespeare bring his murder to light? As described earlier, Shakespeare had Gertrude inform Claudius of the deed in order to provide impetus for his hasty voyage to England. Furthermore, the gruesome responses Hamlet gives in regards to the location of Polonius' cadaver reflect Amleth's. Both characters use their wit to mask the meaning in their words, and in this instance, to mask the location of the dead body.

Curiously, while Shakespeare hides the regicide in the play, but brings Polonius death to light, the Danish legend does the opposite. The difference lies in the time period of the two works. The murder in the closet was kept secret in the Danish version because Fengi could have used the it to justify killing Amleth. Additionally, the murder may have proven detrimental to his 
feigned madness. If the crime had been discovered, the answer Amleth provided would not only prove verified, it would also maintain this ruse. Hamlet's murder is publicized not only to expedite his sea voyage, but also to provide Claudius further reasons to distrust Hamlet.

Like Amleth, Hamlet is sent to England and must intercept the letter ordering his death before arriving. While the voyage is never completed, Hamlet does succeed in foiling Claudius. Additionally, his return leads directly to his revenge. After the voyage, Hamlet no longer pretends to be insane. His confrontation with Laertes in the graveyard in Act 5, scene i, indirectly leads to the fulfillment of his promise to his father. However, Amleth maintains the ruse up until after he avenges his father. Why then does Hamlet not continue?

Before encountering the Danish court, Hamlet reveals to Horatio the circumstances of his voyage, but since Horatio poses no threat to him, Hamlet has no need to maintain the charade. During his conversation, Hamlet is shocked to witness Ophelia's burial. Laertes, who blames Hamlet for her death as well as his father's, jumps into her grave demanding to be buried with her (263-265). Seeing this, Hamlet reveals himself, stating, "What is he whose grief bears such an emphasis, whose phrase of sorrow conjures the wand'ring stars and makes them stand like wonder-wounded hearers? This is I, Hamlet the Dane" (267-271). An enraged Laertes leaps out of the grave and both men proceed to fight.

After their separation, Hamlet declares, "I loved Ophelia. Forty thousand brothers could not with all their quantity of love make up my sum... 'Swounds, show me what thou't do. Woo't weep, woo't fight, woo't fast, woo't tear thyself, woo't drink up easel, eat a crocodile? I'll do 't' (285-294). Gertrude responds, describing his behavior as “...mere madness...” (302), but is it feigned or legitimate?

Was Hamlet legitimately concerned about Ophelia's fate, or was it a ploy to help make his revenge easier? To Horatio, Hamlet states, "What, the fair Ophelia?" (253). He has no reason to maintain the charade with Horatio, who knows of his lie. Having divulged the details of his 
entire scheme to Horatio, Hamlet would have no reason to not inform him of his inauthentic feelings. Thus, this act, while not a ruse, is a genuine act of a mad man. Like Amleth, Hamlet must remain mad until he avenges his father. Attempting to drop the disguise proves foolish; Shakespeare needs to delay his retribution until the play calls for it, thus eliciting authentic feelings of despair and madness over Ophelia's death.

A juxtaposition of Hamlet with the Danish legend then provides reason for Shakespeare's odd use of madness. Studying the play on its own yields no possible explanation for the charade. However, comparing the two reveals Hamlet's reason for adopting it as well as an explanation for his inconsistent portrayal. Hamlet strives to become another incarnation of "The Hero as Fool" story, but cannot live up to the paradigms of the tale because of the medium in which it is told.

Like his madness, Hamlet's delay to act also proves difficult to comprehend by examining the play in isolation. He learns of the regicide through his father's ghost and garners confirmation of the story twice from Claudius, yet still delays. This delay to act cannot be interpreted as hesitation; he was prepared to act when he came upon Claudius alone in Act III, scene iii, but decided against it fearing his murder in during prayer would lead to forgiveness and salvation. Additionally, Hamlet blindly stabs an unknown figure behind the arras, visibly disappointed to see Polonius and not Claudius. Thus, hesitation or fear cannot be the reason. It seems in the play that Hamlet is held back by an unseen force, pushing him through motions that cause him consternation and frustration. As much as he is prepared and willing to act against his uncle, he is unable to. This forced inability to act leads to Hamlet's melancholy. Already melancholic after his father's death, throughout the play, his foiled attempts at revenge cause him to sink deeper into depression.

A reason for his delay that does not harp on his unwillingness to act, and which also illustrates a correlation to his melancholy must be sought. As with his madness, a comparison with the Danish legend provides a reason for both, and also further proves its claim as the Ur- 
Hamlet. "There is no suggestion in the old story of a mental conflict over delayed duty, or the pathos of a desperate situation. The tone is not tragic, but jocular" (Lawrence, "Sea-Voyage" 50). The change Hamlet's temperament must be attributed to Shakespeare's alterations.

The Danish legend follows a basic pattern of events: Amleth is born; shortly thereafter his father is murdered by his uncle. Too young to take the offensive, Amleth decides to feign madness, adopting the rule of the fool at court. After two separate trials, one of which leads to the death of Fengi's trusted advisor, Amleth is sent off to Britain. Foiling yet another plot on his life during the voyage, he arrives safely, causing the death of two of his uncle's men. While there, he wins favor at the court through his wisdom and sound judgment, and is given the hand of the King's daughter to wed. After a year, he returns to Jutland and enacts his revenge scheme, which required an entire lifetime of planning and foresight (Hansen 96-107). Amleth proves ready to enact his revenge only after maturing both physically and mentally.

Thus, Amleth spends an entire lifetime sculpting the perfect revenge scheme. At the start of the narrative, he begins making wooden crooks, and hardening them by the fire. He tells others that they are "sharp spears" to be used to avenge his father, which others interpret as the talk of a fool (Hansen 98). Additionally, before he embarks on his voyage, he tells his mother to celebrate his funeral in a year's time, and to also decorate the hall with woven hangings (Hansen 103). Upon returning a year later, he covers Fengi's drunken co-conspirators and friends with the woven hangings, pinning them down with his wooden crooks before setting them and the hall on fire (Hansen 106). He faces Fengi as a grown man.

While in Britain, Amleth proves to have an immense capability of foresight, and avoids consuming tainted food and reveals an unknown truth of the King and Queen (Hansen 104). “A part of the primitive Hamlet-story... involved Amleth as something of a wizard" (Stabler 207). Saxo provides no explanation for how Amleth could have correctly surmised where the tainted food originated. Additionally, Amleth also informs his companions of the King and Queen's 
lowly origins, claiming to know based on perceptiveness (Hansen 104-105). This perceptiveness, verging on wizardry, aides Amleth in preparing the perfect revenge plot.

Every action in Amleth's life leads to the eventual moment when he is able to avenge his father. The act cannot be enacted at the start of the story due to Amleth's age as well as lack of preparation. Only when he has grown can he act. His combination of wit, foresight, and borderline witchcraft come together to provide the story with a clean act of revenge.

Hamlet also follows a similar chain of events, with slight modifications implemented by Shakespeare. For example, even before the Ghost scene, Hamlet is depicted as a melancholic character, continuing to mourn for his father and angered by the court's lack thereof. Additionally, he expresses disbelief at his mother's hasty marriage, stating, "Why she (would) hang on him as if increase of appetite had grown by what it fed on" (I, ii, 147). His melancholy, attributed to the recent state of affairs, is only exacerbated as the play unfolds and he continues to delay.

Hamlet is presented with various opportunities in which to act before finally carrying out the revenge. Unlike Amleth, he has no need to delay; Hamlet is strong enough to carry out revenge and has no need to postpone it. Additionally, whereas Amleth takes time to carefully plan, Hamlet does not need to. Why then does Hamlet continue to delay?

When he first hears of the crime in Act I, scene i, from the Ghost, Hamlet states, "Haste me to know 't, that I, with wings as swift as meditation or the thoughts of love, may sweep to my revenge" (35-37). Hearing the whole story, he quickly writes the Ghost's final words, vowing to remember the Ghost as well as avenge his father's death (117-118). Rather than head straight to a confrontation with Claudius, Hamlet appears to Ophelia instead, visibly disturbed (II, i, 87-112). Shakespeare describes no attempts made by Hamlet at this point to seek Claudius, nor has Hamlet begin to formulate a master plan. 
His failure to act swiftly after hearing the Ghost's words leads to his verbal assault on himself in Act II, scene ii. He calls himself a "rogue" and "peasant slave" (577), despairing at his inability to act in comparison to that of the Players, who give it their all for a nonimportant play: "Yet I, a dull and muddy-mettled rascal, peal like John-a-dreams, unpregnant of my cause, and can say nothing... Am I a coward... For it cannot be but I am pigeon-livered and lack gall to make oppression bitter..." (593-605). His feelings of frustration and anger at himself only worsen as his tirade continues: "(O vengeance!) Why, what an ass am I! this is most brave, that I, the son of dear father murdered, prompted to my revenge by heaven and hell, must like a whore, unpack my heart with words and fall a-cursing like a very drab, a (scullion)! Fie upon 't! Foh!” (610616).His words reveal a man who eagerly wishes to act, but cannot.

However, he provides an excuse for his delay, ending his self-deprecation. Hamlet has no evidence to substantiate the Ghost's claims of both parentage and regicide. He declares, "The spirit that I have seen may be a (devil,) and the (devil) t' assume a pleasing shape; yea, and perhaps, out of my weakness and my melancholy, as he is very potent with such spirits, abuses me to damn me" (627-632). "Hamlet delays because of his fear that the Ghost may not be a duly authorized heavenly messenger and that he may therefore be about to commit a mortal sin in an act of private revenge" (Stabler, "Melancholy" 212). Thus, he decides to ascertain the Ghost's claims before continuing.

Witnessing Claudius' reaction to the play in Act III, scene ii, confirms the Ghost's story. Exuberant, Hamlet declares, "I'll take the ghost's word for a thousand pound. Didst perceive?" (312-313). He calls for music, and proceeds to sing. Learning that his mother requests his presence in her room, he states, "Now could I drink hot blood and do such (bitter) business as the day would quake to look on" (422-425). With this in mind, Hamlet decides to seek Claudius before visiting his mother. 
Hamlet finds Claudius alone and at prayer. Drawing his sword, he realizes that were he to kill Claudius in prayer, his soul may go on to heaven:

"That would be scanned: a villain kills my father, and for that, I, his sole son, do this same villain send to heaven. Why, this is (hire) and (salary,) not revenge. He took my father grossly, full of bread, with all his crimes broad blown, as flush as May; and now his audie stands who knows save heaven... up sword, and know thou a more horrid hent. When he is drunk asleep, or in his rage, or in th' incestuous pleasure of his bed... then trip him, that his heels may kick at heaven, and that his soul may be as damned and black as hell, whereto it goes."

(III, iii, 80-100)

As with the previous instance, Hamlet's lack of action is not due to hesitation or unwillingness; rather, he is waiting for the opportune moment to strike. Killing Claudius at this point would not prove wise. Instead, Hamlet decides to seek a better opportunity.

Directly following this scene, Hamlet heads to his mother's chamber. Again, this does not illustrate an unwillingness to act. Hamlet is undergoing actions thrust upon him by the plot of the play which he must undergo before seeking revenge. After arriving in her chamber, Gertrude, worried for her life, cries out in fear of her son. This prompts Polonius to cry out as well from his hiding spot. Hamlet does not wait to ascertain the mysterious person's identity and instead, kills him (III, iv, 28-30). Disappointed, Hamlet cries, "I took thee for thy better" (39). Again, Hamlet does not demonstrate an inability to act; in fact, it shows an eagerness to do so. However, as in the earlier instances, he is prevented by outside means from doing so.

The failed murder prompts hamlet to launch an entire tirade against his mother, lamenting her immoral behavior and reminding her of his father. He is not attempting a conversation; he is instead vocalizing his frustration at both his situation and inability to do something of it. The ghost appears. Hamlet proceeds to apologize for his delay: "Do you not come your tardy son to chide, that, lapsed in time and passion, lets go by th' important acting of your dread command?" (III, iv, 122-123). The ghost's accusations of his failure to act are undeserved. Hamlet has acted; circumstances have prevented him from fulfilling his mission, however hard he may have tried. 
The events of this scene directly lead to Hamlet's forced voyage to England, which further prevents him from acting.

Before leaving to England, Hamlet encounters Fortinbras. Hearing of the similar circumstances surrounding their lives, Hamlet laments that he is unable to act like Fortinbras does. He cannot understand what is preventing him from acting, leading to his frustration and despair: "Now whether it be bestial oblivion or some craven scruple of thinking too precisely on th' event... I do not know why yet I live to say 'This thing's to do,' sith I have cause, and will, and strength, and means to do "t" (IV, v, 41-49). He continues his assault, stating, "O, from this time forth my thoughts be bloody or be nothing worth!" (IV, v, 68-69). His reactions indicate a willingness to act, yet mass frustration at his inability to do so.

Upon returning from England, he is again prevented from carrying out his revenge. As discussed earlier, Ophelia's death and Laertes' rage forces Hamlet to postpone his actions. Additionally, as in the prayer scene, he cannot attack the King in the graveyard since it is a sacred place $(\mathrm{V}, \mathrm{i}, 272-311)$. He is forced to continue to delay.

However, this time Hamlet reacts differently. In Act V, scene ii, he reveals the mental tumult he suffered while on the ship: “...[I]n my heart there was a kind of fighting that would not let me sleep... Our indiscretion sometimes serves us well when our deep plots do pall; and that should learn us there's a divinity that shapes our ends, rough-hew them how we will..." (4-12). The speech reveals that Hamlet has come to a rather important realization; as much as he may plot to kill Claudius, an outside force ultimately dictates how events will happen. He is hopeless to change that and unable to do so. Horatio urges him to act, fearing that once the king discovers Rosencratz and Guildenstern's fate, he will order Hamlet's death (70-82). However, Hamlet seems oddly calm.

This is the same character who in an earlier act, expressed an urgent need for revenge, and who blindly committed murder. Hamlet is different here because he understands that his fate 
is not in his hands. Throughout the play, he tried to create circumstances that would allow him to kill his uncle, none of which prove successful. He finally realizes that there is something else controlling his fate, and preventing him from doing so until the time is right. "All tragic heroes experience themselves as passion's slaves. Perhaps what is 'intellectual' about Hamlet is that he is aware that he does so. His tragedy focuses on this predicament itself" (Birenbaum 27). It is only after the realization that he is not in control of his fate, and that he is indeed "passion's slave" that he is able to act. Martin Stevens provides further explanation for this realization:

"As usual in Shakespeare, the macrocosm reflects the microcosm; the church- yard in which we reencounter Hamlet reflects, in tonality if not in image, his new state of mind. He has been transformed by his sea adventure, an occurrence that has rightly been deemed of important spiritual significance. The self-generating actor, the player extraordinaire, the man who sees himself as minister and scourge has discovered that his own designs are insufficient, that there is, indeed, 'a divinity that shapes' our roughhewn ends"

Realizing that plotting is futile, he decides to allow fate to guide his hand, causing his melancholy and self-deprecation to abate.

With this new resolve, Hamlet gains the foresight present in his predecessor. In Act V, scene ii, he comes to the realization that he must die in order to carry out his revenge. In regards to the duel with Laertes, he states, "I shall win at the odds; (but) thou wouldst not think how ill all's here about my heart. But it is no matter" (225-227). This is a character who made known throughout the play the feelings etched in his heart; the last line stated demonstrates the change in his character. His prophetic feeling does not usher in a philosophic soliloquy; instead, Hamlet is finally given the freedom to act and proceeds to duel. He is finally able to enact his revenge, but perishes in process as predicted. With his dying breath, rather than lament his state of being as would a Hamlet in an earlier act, he imparts a vision of the future onto Horatio: "But I do prophesy th' election lights on Fortinbras" (391-392). Shortly thereafter, Fortinbras appears, affirming Hamlet's prediction and becoming the new King of Denmark. 
Thus, Hamlet is not capable of controlling his inability to act. Each time he attempts to fulfill his promise, outside forces step in, preventing him. He waits to prove the Ghost's claim, fearing trickery. He is thwarted again on the verge of action by his uncle's prayer. When he is finally able to act, he kills Polonius instead of Claudius. Returning from England, he delays in shock of Ophelia's death, and then upon word of Laertes' challenge. The source of Hamlet's delay, then, is not internal.

Hamlet is delayed not of his own accord. Why would Shakespeare present Hamlet with a situation, urge his action, yet prevent him from doing so? By borrowing the major elements from the Danish legend, Shakespeare inadvertently cursed his own main character. "Hamlet, so far as it's a study of its chief character, is perhaps the most impressive example in literature of a titanic spirit thrashing around in the prison of what it is" (Frye, "Hamlet" 99). The difference between Hamlet and his archetype directly leads to his inability to act and his melancholy. He is ready to act, but Shakespeare does not provide him with the means to do so and is stunted by the plot. The archetype he is based on is forced to delay for lack of preparedness. In the Danish legend, Amleth is not seen as one who hesitates; transferring the same circumstances and desires onto Hamlet changes that. Rather than provide Hamlet with the same opportunity given to Amleth which granted him time to develop mentally and physically, Hamlet is thrust into the poised for action. However, he is ultimately prevented from doing so because of the original story's timing of events.

The Danish legend's claim as the Ur-Hamlet has been corroborated thus far. Like other elements from the original, Shakespeare's borrowing of the story's timing explains Hamlet's delay and provides a valid reason for the self-loathing that comes from his incapability to act. Additionally, the Danish legend also sheds light on the purpose of the sea voyage. Any type of journey over a body of water is a necessary aspect of the Hero Legend, for it is through that body of water that the hero's death sentence and ultimate salvation through the assistance of animals or 
low-born people is carried out. Without the comparison, Hamlet's voyage seems odd. Yet again, not only does a comparison to the $U r$-Hamlet provide reason for the event, it also reveals aspects of the play not directly stated by Shakespeare.

Thus, a major point of the Hamlet story involves a voyage to England thrust upon Hamlet by Claudius. It is during this voyage that Hamlet discovers his uncle's plot to kill him. However, this action all happens off stage, and Hamlet never actually arrives in England. Instead, he boards a pirate ship which, in return for a "good turn," provides him passage back to Denmark (IV, vi 13-29). However, "[i]t is an odd feature of the greatest of English tragedies that the hero disappears completely from view for a considerable time, and even leaves the country in which the action takes place" (Lawrence, "Sea-Voyage" 45). The titular character remains absent from Act IV, scene v, until Act V, scene i: a total of three scenes. Additionally, not much is known of the mission itself:

"The mission to England, both in its planning and in its execution, takes place entirely offstage; we therefore derive all of our information about it from what the characters say. And since Shakespeare, probably quite deliberately, has provided us with only the most skeletal details, we are left with only a hazy impression of what actually transpired"

(Stevens 276)

The scene also varies from that of the Danish legend, which lacks pirates and allows Amleth to complete his voyage.

Some say that this element does not point to the Danish legend, but rather to Kyd. Even if one were to argue for Kyd's authorship, his “...management of Hamlet's return... has no pirates,” indicating that "...Shakespeare altered the adventure to the form in which we now have it" (Lawrence, "Sea-Voyage" 53). Examining the purposes of the voyages in both Hamlet and the Danish legend, however, reveals similar outcomes.

In the Danish legend, Fengi decides to send Amleth away after the murder of his advisor, suspecting him of deception and wishing his murder, yet not willing to play a direct role in it. Amleth travels to England with two of Fengi's housecarls. As mentioned earlier, he finds the 
letter decreeing his death and alters it, stating that the housecarls were to be put to death and that the King of Britain should give his daughter to the "very intelligent youth he was sending him". Upon arrival, the King of Britain read the letter and invited him to a feast. During the feast, Amleth chose to forego the food and the drink. When asked why, he revealed that the food was tainted with blood and with death. Additionally, Amleth reveals truths of the King and Queen's low parentage. After investigating, the King found all that he said to be true, thus proving Amleth's wisdom and spurring him to finally give his daughter to the wise man. After a year, Amleth returns to Denmark and enacts his revenge (Hansen 103-106). "The framework is familiar: a hero comes from afar to a kingdom where he wins renown and the hand of a princess. He distinguishes himself in this instance, and gains the favor of the king, by cunning rather than by valor, fathoming the mystery of the food and drink at the banquet, and of the royal parentage" (Lawrence, "Sea-Voyage" 49). While not original to neither Saxo nor Belleforest, the story follows the event actions as outlined in the "Hero as Fool" myth.

Shakespeare's account of events differs greatly. First of all, Claudius plans to send Hamlet to England before the closet scene. In Act III, scene i, after eavesdropping on his conversation with Ophelia, Claudius states, “Thus set it down: he shall with speed to England for the demand of our neglected tribute. Haply the seas, and countries different, with variable objects, shall expel this something-settled matter in his heart..." (183-187). Based on this declaration, one is left to wonder if Claudius is aware of the threat Hamlet poses.

Unfortunately, Shakespeare remains unclear on the matter. What is certain is Claudius' intent on removing Hamlet from court. Martin Stevens provides some clarity to this act:

"Shakespeare clearly intended to give only a vague account of Claudius' plotting and Hamlet's counterplotting in Act III; he wanted his audience to know only that the voyage to England was imminent and that both Claudius and Hamlet knew what they were up to. Hence, it matters little just when Claudius decided to change the intent of the mission or just how Hamlet found out about it... What is important about the mission to England in Act III is thus clearly established: the spectator must realize that Claudius is developing a 
plan to remove Hamlet and that Hamlet, in turn, has become aware of that plan and is formulating his own plan in response"

However, one is left to wonder why in Act I, Hamlet's requests to return to school in Wittenberg is denied by Claudius (116-123).

If Claudius suspected Hamlet, why not allow him to return to school? This would have been a wise course of action on Claudius' part. However, he asks Hamlet to remain at court. Had he been allowed to return, the play could have still been carried out in a similar fashion, this time Hamlet playing a similar role to Fortinbras, seeking vengeance from afar and amassing an army. However, Shakespeare here hints at the fact that Claudius believed Hamlet to be not a threat. He asks Hamlet to stay at court because his predecessor Fengi kept his step-son at court as well. As much as he would have benefitted from his removal, Claudius cannot have Hamlet leave and likewise, Hamlet is equally bound to the court. Therefore, at first, the mention of the voyage to England is harmless.

After the events of "The Murder of Gonzago," Claudius again mentions Hamlet's voyage to England, commanding Rosencratz and Guildenstern to deliver him hence: "I like him not, nor stands it safe with us to let his madness range. Therefore prepare you. I your commission will forthwith dispatch, and he to England shall along with you" (III, iii, 1-4). Still, Hamlet remains at court long enough to murder Polonius in Act III, scene iv. This act is what finally leads to the voyage. In the Ur-Hamlet, Amleth only leaves after submitting to two trials, and murdering an advisor. Even though Claudius wishes Hamlet to embark sooner, the time line and sequence of events imposed by Shakespeare prevents his removal from happening.

Finally, in Act IV, scene iii, Hamlet finally embarks. Like Fengi, Claudius cannot murder Hamlet himself. Claudius states that Hamlet is "loved of the distracted multitude" (4) and must therefore be sent to England rather than endure "strong law" for the murder of Polonius. In a soliloquy, Claudius reveals that, like Fengi, he plans on having the King of England murder 
Hamlet rather than himself: “...[T]hou mayst not coldly set our sovereign process, which imports at full, by letters congruing to that effect, the present death of Hamlet" (71-74). Thus, while the timing may differ, both voyages are a direct result of the mistrust felt by Fengi and Claudius. However, from this point on, Shakespeare makes various changes to the original story.

Both Amleth and Hamlet are accompanied by two of the King's men, each with a letter ordering his death. Saxo describes how Amleth alters the letter: "But while the two were sleeping, Amleth searched their coffer and found the letter. He read its contents, scraped off what had been carved, and substituted different runes, changing the sense of the message and transferring his own doom to his companions" (Hansen 103). Hamlet alters the letter as well. He describes to Claudius how he found the letter:

"Up from my cabin... in the dark groped I to find out them; had my desire, fingered their packet, and in fine withdrew to mine own room again, making so bold (my fears forgetting manners) to unfold their grand commission; where I found, Horatio, a royal knavery-an exact command... that on the supervise, no leisure bated, no, not to stay the grinding of the ax, my head should be struck off"

(V, ii, 15-28)

Once he discovers the letter, Hamlet describes how he altered it: “...That, on the view and knowing of these contents, without debatement further, more or less, he should those bearers put to sudden death..." (49-51). "Shakespeare must have derived from Belleforest Hamlet's reading of the letters and altering their content while the messengers sleep, so that death overtakes these men in England" (Lawrence, "Sea-Voyage" 55).

Both alterations by the main character then now only serve as their salvation, but also a means of death to their companions. However, in Hamlet, these men sent by Claudius were Hamlet's friends. Were Rosencratz and Guildenstern willing participants in Hamlet's murder? Shakespeare neither confirms nor denies it. While they do lose Hamlet's trust when he realizes they are questioning him at the request of his uncle, in the play, their actions seem harmless. Their death unveils more evidence of the heavy borrowing done by Shakespeare. 
In Amelth, their allegiance is not explicitly stated, but examining their role in the legend hints at the role played by Rosencratz and Guildnestern:

"There is some probability that in [the earlier story] they were guilty. The sources point in that direction, and in melodramatic tragedies the personages were pretty much all black or all white-and the hero's adversaries not among the white ones... It may be argued, then, that Shakespeare... let this situation stand."

$$
\text { (Lawrence, "Sea-Voyage" 59) }
$$

Because their predecessors in this scene were Amleth's adversaries, one can assume that

Rosencratz and Guildenstern were as well. Like Ophelia, they come to embody multiple personas. They act as Hamlet's school friends before oddly shifting to Claudius' spies. Their final role then is that of accomplices to murder.

Shakespeare choice of including Hamlet's death in a letter again indicates a borrowing from the Danish legend. However, in borrowing from Danish tradition, Shakespeare also borrows an element seen in "nearly all civilized peoples of the ancient world" (Lawrence, "Sea-Voyage" 59). This element, called "Das Glicks- kind mit dem Todesbrief," roughly translates to "The Child with the Death Letter." Like "The Hero as Fool," this story also has a basic plot line. According to William H. Lawrence,

"The hero overcomes the machinations of a deadly enemy; he is to deliver a letter, which calls for his own death, but by good fortune, or the intervention of friends, or of a maiden who loves him, or of higher powers, he wins in the end a bride and sovereignty"

("Sea-Voyage" 50)

Shakespeare retains the beginning of this tale and incorporates all aspects except marriage, since Hamlet is never given the opportunity to deliver the letter himself.

Whereas Hamlet returns quickly, Amleth spends an entire year in England. "It is, as is well known, an almost vestigial relic of a long adventure which, in the old tale of Amleth, occupied a whole year in the hero's life" (Lawrence, "Sea-Voyage" 45). It is in this year that Amleth not only matures, but also marries the King of Britain's daughter. It is in this dinner that he correctly guesses the origin of their meals as well as the King and Queen's birth. "Thus the 
rudeness of the prince at the royal banquet, the king's admiration for him and willingness to admit proof of his own base birth and that of his queen, are clumsy expedients to show Amleth's cunning" (Lawrence, "Sea-Voyage" 51). The year then serves as a means of proving to the audience Amleth's readiness to act. He returns poised from Britain, ready to enact revenge.

However, Hamlet does not even make it to England and is not given the opportunity, like Amleth, to display his cunning. "The reason for this change is obvious: the hero's long stay at the English court and his adventures there in the old tale are not suited to the stage. The dramatic problem was how to get him back to Denmark immediately, while Rosencrantz and Guildenstern go on to their death. This was neatly done by the pirate attack" (Lawrence, "Sea-Voyage" 52). Thus, the inclusion of the pirate attack allows Hamlet to embark on his voyage, alter the letters, and with the pirates, return to Denmark immediately.

One could argue that the inclusion of the pirates eliminates the Danish legend's claim as the Ur-Hamlet, since no such pirates are mentioned there. Some argue that Shakespeare borrowed this element from a separate work:

"Parrott and Craig believe that the pirate incident was 'plainly suggested by Shakespeare's recent reading of Plutarch's Life of Caesar.' It will be noted, however, that the resemblance of this to Shakespeare's play consists solely in that the prisoner was well treated, and ultimately released"

(Lawrence, "Sea-Voyage" 54)

But, to reiterate, the only similarities lie in the fact that both works included pirates. No further similarities exist.

An explanation for Shakespeare's pirates lies in the time period this play was set on stage. Pirates were a well-known threat during the Elizabethan era: "Pirates were so constant a menace in the North Sea in the days of Elizabeth, and so familiar to everyone, in fact and fiction" (Lawrence, "Sea-Voyage" 54). So familiar were pirates “...that one hesitates to say that those in Hamlet must have been due to Shakespeare and not to Kyd..." (Lawrence, "Sea-Voyage" 54). Because of their popularity, then, one must consider the usage of pirates a stylistic choice. 
In the "'Hero Legend', as outlined by Otto Rank, the hero is saved from death by either animals or common people. While the two characters do save themselves by altering their letters, the ultimate saviors do fit Otto's outline. Amleth is provided asylum in Britain by a King, who is later revealed to be born of a servant. Amleth's pirates ultimately step in, providing him safe passage to Denmark. With this, both the legend and Hamlet fulfill include the tenants of the "Hero Legend"

The pirates then, while not originating from the Danish legend, do serve as a means of disproving the other possible contenders for the Ur-Hamlet as well. "If Shakespeare did introduce the pirates... one interesting conclusion follows: that he went independently to Belleforest..." (Lawrence, "Sea-Voyage" 54). To reiterate, Shakespeare's inclusion of pirates indicates that while the idea for the event was borrowed from either Saxo or Belleforest, the addition of pirates comes from the author himself. "...[C]ommentators on Hamlet have perpetuated the view that Shakespeare uses the intervention of the pirates as a deus-ex-machina device or, in Christian terms, as a providential event to bring about Hamlet's return to Denmark and prepare for his ultimate confrontation with Claudius" (Stevens 276). Thus, the pirates' inclusion in Hamlet serves a dual purpose: it serves as a mechanism to bring about Shakespeare's return to Denmark, and also illustrate Hamlet's foresight and wit.

Like Amleth, Hamlet also displays almost prophetic foresight in the events surrounding this voyage. While in his mother's chambers, Hamlet reveals to her that he is aware of his upcoming trip, and the means by which he will embark on it:

"There's letters sealed, and my two school fellows, whom I will trust as I will adders fanged, they bear the mandate. They must sweep my way, and marshal me to knavery. Let it work, For 'tis the sport to have the enginer hoist with his own petard. And 't shall go hard But I will delve one yard below their mines and blow them at the moon: Oh, 'tis most sweet When in one line two crafts directly meet."

(III, iv, 225-233) 
The speech reveals that Hamlet is aware of the coming events and of his impending voyage, which have not been made known to him yet. "The last sentence of the passage makes it clear beyond dispute, with its pun on craft, that Hamlet has engaged the pirates for the rendezvous at sea. The text thus establishes the fact that Hamlet has planned in advance for the intervention of the pirates" (Stevens 279). The speech reveals that Hamlet is aware of the plans for his voyage. Additionally, he also insinuates that he will be able to return to Denmark; the two crafts meeting refer to the ship bearing him towards England and a second ship that will ensure his return. Thus, while Hamlet is unable to act in regards to his vengeance, he is able to act in preservation of his own life. This plot shows foresight and planning that many argue Hamlet lacks.

Further proof of Hamlet's plan lies in his letter to Horatio in Act IV, scene vi. In it, he describes his very odd rescue at sea:

"Ere we were two days old at sea, a pirate of very warlike appointment gave us chase. Finding ourselves too slow of sail, we put on a compelled valor, and in the grapple I boarded them. On the instant they got clear of our ship, so I alone became their prisoner. They have dealt with me like thieves of mercy, but they knew that they did: I am to do a good turn to them"

"The latter clause is intriguingly vague. It readily suggests in its preterit construction that the whole encounter was planned in advance" (Stevens 279). Thus, Shakespeare provides evidence that Hamlet orchestrated the pirate attack. Unable to have his character spend a year in England, he incorporated a circumstance menacing to England and provided means for his character to manipulate that menace for his own means. The pirates in Hamlet can thus be likened to the revelations Amleth makes in the Danish legend; both were problems both characters utilized in schemes that helped underscore their foresight.

The voyage Hamlet undertakes, borrowed from the Danish legend by Shakespeare, thus serves multiple purposes. While seemingly unimportant on its own, a juxtaposition with the Danish legend reveals not only its importance, but also helps verify its claim as the Ur-Hamlet. 
The extent of the borrowing is not limited to the act itself; both characters' voyages result in personality changes: Amleth arrives finally ready to seek vengeance. Hamlet, on the other hand, returns and achieves mental peace, no longer verbally self-mutilating and willing to wait for an outside force to provide an opportunity for his revenge. Each character is sent to their death by means of a body of water and is able to foil their murderers as well as show their cunning and readiness.

The sea voyage in Belleforest and Saxo serves as a catalyst to the final act of revenge.

As an integral role in the Danish legend, it could not have been eliminated.

"Had Hamlet not been capable of quick action, he would never have survived the fight with the pirates. Had he not hesitated in his revenge, he would never have been sent to England. The sea-voyage was in the story, and there it had to stay. The more carefully the ways in which Shakespeare overcame this technical difficulty are studied, the more remarkable does his final achievement appear"

$$
\text { (Lawrence, "Sea-Voyage" 50) }
$$

Thus, the legend serves as a tool by which Hamlet can be better comprehended. On its own, the sea voyage seems an odd inclusion, and unnecessary. However, comparing Hamlet's journey to Amleth's, while not an exact replica, does reveal its importance to the plot, as well as a tool to unveil the truth of Hamlet's character.

Whereas Hamlet's madness, delay, and voyage to England can be traced to the Danish legend, and help affirm its claim as the Ur-Hamlet, the Ghost as it is represented in Hamlet cannot. "The Hero as Fool" and forms of the Hero Legend do incorporate supernatural elements, but none to the extent of the Ghost in Hamlet. Belleforest can be credited as being the first to introduce a Ghost character to the tale, but mentions him only vaguely. Shakespeare expands his role, but in doing so, creates one that resembles Ghosts in other revenge tragedies, leading many to discredit the Danish legend as the Ur-Hamlet.

While the Ghost only appears three times, remaining silent during its first appearance, it plays an important role in the play. Through the Ghost, Hamlet learns of his father's murder. The 
Ghost also appears to Hamlet in his mother's chambers, reminding him of his vow to avenge him. Since the murder is publicized in the legend, there was no need for a Ghost who reveals the crime. What prompted Shakespeare to include a Ghost in his version? Additionally, does this Ghost dismiss the claims the Danish legend has to the Ur-Hamlet?

Many believe that the Ghost does dismiss those claims, and suggest the title of $U r$ Hamlet more readily suits Antonio's Revenge, which utilizes a Ghost similarly. However, Chapter II discussed the incongruities with the timing and authorship of the plays, and determined that both Hamlet and Antonio's Revenge to have been written within the same time frame. Further dismissing that theory, Donald McGin writes:

"Marston's abrupt change of mood... and the other inconsistencies of the later play, would therefore indicate that something must have induced him to alter his original plan for [Antonio's Revenge]. The striking resemblance of Antonio's Revenge to Hamlet arouses suspicion that Marston, having seen Shakespeare's revision prior to the composition of his second play, may have decided to try his hand at the tragedy of revenge"

Assuming Shakespeare borrowed the Ghost from Marston then proves false, as it is more likely the opposite occurred. Additionally, many believe the work Nashe refers to in his epistle, which features a ghost who cries, "Hamlet, revenge" (Clark 80), refers to a lost play written before Hamlet which Shakespeare used. However, in Section 1, the existence of this piece described by Nashe was shown to be unsubstantiated.

Looking at the play, the characterization of the Ghost itself is not typical to Shakespeare. According to Cumberland Clark, "The long speeches in [Act I,] Scene V with their invective and moralization are not at all characteristic of Shakespearean ghosts, who are usually the most reticent of beings" (Clark 80). However, Clark goes on to admit that the Ghost's second appearance differs from the first: "On this occasion, the ghost limits itself to half a dozen lines... This is more typical of Shakespeare's use of this particular form of the Supernatural... [T]he second visit was Shakespeare's own invention" (Clark 80). Thus, a disparity exists in the play. 
However, examining Shakespeare's purpose for including the Ghost provides reason for the inconsistency.

Shakespeare was writing in a time that popularized elements of the supernatural: "They demanded fairies, ghosts, and witches... and Shakespeare continually made concessions to this demand and packed his plays with popular opinions on the Supernatural" (Clark 40). This is why so many of his plays incorporate witches, fairies, and other mystical creatures. "The Hamlet Ghost fulfills all the demands of popular superstition. In the first place it comes in strange and creepy circumstances, at dead of night, which it is cold and still and lonely" (Clark 65). His usage of this element, then, can be explained as a means of incorporating a trend of his era.

The supernatural was so popular that several playwrights introduced elements of that nature solely to please the public, which proved unnecessary to their plots. Shakespeare, while never succumbing to this pressure, was able to include supernatural aspects in his plays by providing them just cause for existing (Clark 70). Thus, Shakespeare became a master of the supernatural, but "...not until Hamlet did he develop it fully and demonstrate the dramatic use of the ghost-belief in its most powerful and impressive form" (Clark 64). The Ghost in Hamlet then becomes a culmination of Shakespeare's usage of the supernatural.

Shakespeare's success with the supernatural lay in his skill of incorporating them into his plot. "He was always careful to give his ghosts an essential part to play and never introduced them as meaningless supernumeraries. The Hamlet Ghost... dominates the whole action, and controls the fortunes and characters of all who come beneath its influence" (Clark 81). Mary A. Woods states, "They are no mere stage accessories. They have a function and a dignity that compel the awestruck recognition of the most careless" (Clark 81). The popularity of the supernatural as well as Shakespeare's choice of inclusion would thus explain its echoes in various plays of the time. A play which incorporated a Ghost would not seem odd; it would simply be a reflection of the desires of a playwright's audience. 
Additionally, the Elizabethans had a concrete set of beliefs in regards to ghosts and spirits. This was reflected in plays in which they were utilized, providing an explanation for the similarities present in the numerous ghosts incorporated in revenge tragedies. For example, one needed to be educated in order to communicate with Ghosts: "Not only were apparitions silent until addressed, but it needed an educated man to make them talk. All exorcists were supposed to be learned and fluent in the Latin tongue" (Clark 65). This would explain why Marcellus' urges Horatio, a scholar, to speak to the apparition in Act I, scene i (49).

While the means of addressing ghosts was universally accepted, two distinct theories existed regarding the origin of ghosts. According to Cumberland Clark, people's opinions varied depending on their level of education:

"The first, and that in which the more educated people concurred, maintained that their origin was evil, that they were devils from hell, charged with a special mission to earth which could only be conveyed by supernatural means, and that they adopted for their purpose the form, figure, and characteristics of a deceased person. The second opinion interpreted ghosts as the actual spirits of departed men and women, who rose from the grave and appeared in a form recognizable to those still living, in order to impart information of the first consequence."

(Clark 68)

In Act I, scene iv, Horatio advises Hamlet against following the Ghost because he believed the first reason. However, Barnardo and Marcellus, lacking the intelligence that Horatio possesses as a scholar, express no doubts of the Ghost's identity.

When they did make themselves known, the consensus was that they "... were thought to appear before some great crisis in human affairs, to exact justice, to revenge a foul deed, to give a warning, to reveal hidden treasure, or otherwise perform the commands of the supernatural powers" (Clark 66). Ghosts were permitted to return to Earth to complete a specific task. However, their task needed to be completed through a human. "The Ghost had no power to float into the Castle at Elsinore and slay Claudius with its own hands. It must choose the living Hamlet as an instrument; and even then, it could not insist on his carrying out the task of revenge. It could 
only spur him on in the hope that the deed would be done" (Clark 75). This explains the flood of Ghosts present in Elizabethan revenge tragedies. Each one returns to Earth seeking vengeance, but cannot on their own, prompting them to seek out a mortal's assistance.

Additionally, Ghosts would unveil the suffering present in the afterlife, not the joy (Clark 66). This would explain the similar depictions of the afterlife presented by the Ghosts in both Hamlet and The Spanish Tragedy: "When they do lift the curtain, it is a peep at hell they give us, not a peep at heaven" (Clark 66). The fiery depictions each Ghost present are not an invention of the playwright, but a statement ascertaining the beliefs of the Elizabethans.

The similarities then between Ghosts can be attributed to Elizabethan superstition. Because of this, an inclusion of a Ghost in a play does not automatically demonstrate borrowing; therefore, Shakespeare's incorporation of a Ghost cannot indicate a borrowing from another play. This alone does not corroborate any work's claim as the Ur-Hamlet, since ghosts were used in various plays. While this explains Shakespeare's reason to incorporate a ghost in his work, the question regarding the origin of his ghost as well as role in the play does remain.

It is true that Shakespeare's ghosts did play an essential role in his plays. The only character from the Danish legend that could be transformed into a Ghost, and remain essential, is Horwendil, Amleth's father. However, the Ghost in Hamlet only states he is Hamlet's father, which may or may not be true. After Claudius' admission of guilt, the Ghost's claims are verified, revealing the Ghost to be the spirit of King Hamlet and not of demonic origin.

Very little is known of either character. From the legend, one can ascertain that Horwendil "won outstanding glory as a Viking," spoke bravely, fought aggressively, and won favor in court through his battles. Additionally, the legend describes a duel held on an island between Horwendil and the King of Norway, which Horwendil proved victorious (Hansen 9597). Murdered by his brother, his death serves as a catalyst for the revenge and madness in the narrative. 
Like Horwendil, little is known of King Hamlet as well. "We know that he was courageous, but high-tempered... He had 'an eye like Mars to threaten or command'; he was sent to his account unshriven, with all his imperfections on his head, guilty of 'foul crimes done in my days of nature..." (Wiley 18). Additionally, King Hamlet also fought and killed the King of Norway (I, i, 93-98). This character too was murdered by his brother, and his appearance to Hamlet as a Ghost spurs Hamlet to feign madness while seeking revenge.

The little that is known of both characters is so similar that one must assume Shakespeare had Horwendil in mind when creating his Ghost. He is the only character who could plausibly assume this transformation. Additionally, Hamlet and Amleth share similar reactions to the deaths of these characters, which incite them to revenge their murders. However, a major difference between the characters centers on their initial acceptance of the death. Amleth never doubts the events of his father's murder, while Hamlet does.

Applying the Elizabethan's supernatural beliefs to the story explains why Hamlet at first doubts the veracity of the Ghost. "In Shakespeare, of course, it is the Ghost who informs Hamlet of the hitherto concealed past event, and Hamlet, well aware of the danger implicit in his melancholy humor, does therefore suspect the Ghost of being a devil" (Stabler, "Melancholy" 208). Here, Hamlet expresses a common fear of the Elizabethan era involving ghosts. "Hamlet cannot shake off his old beliefs and feel convinced that the apparition was in very truth his father returned from the dead. The call to revenge falls on doubting ears and results in hesitancy and inaction" (Clark 69). As described earlier, this doubt is a cause of Hamlet's delay.

In order to prove the Ghost's claims, Hamlet stages “The Murder of Gonzago.” In addition to an attempt to implicate the King by studying his reaction, the play also serves as a means of justifying the Ghost. Its claims justified, Hamlet no longer has cause for concern of the Ghost's origins. "The Murder of Gonzago" proves that the Ghost is a manifestation of King Hamlet and, by extension, a predecessor of Horwendil. However, attributing Horwendil's 
transformation in Hamlet to the demands and desires of the Elizabethan people is correct, but too basic. Shakespeare's reason for including the Ghost delves deeper than that.

In addition to being a popular motif, Shakespeare could also have received inspiration for his Ghost from the legend itself. Both Saxo and Belleforest translated the legend of Amleth, and both kept the story-line intact. However, Belleforest does include slight modifications to the story not found in Saxo, one of which being a Ghost, as mentioned earlier. Additionally supernatural elements are incorporated in his version as well. While brief, the "...passage in Belleforest that refers to the supernatural is, nevertheless, very significant" (Wiley 24).

In Belleforest's version, Amleth could see events that had occurred in the past (Wiley 24) but was in danger of the devil's influence because of this power (Stabler, "Melancholy" 208). This of course would not have worked on Shakespeare's stage. Transferring this power onto a Ghost, however, would prove plausible. Building on this element from Belleforest explains the Ghost's speech in Act I, scene v, which Clark argues is not typical of Shakespeare's usual ghosts. Its atypical nature here is due to this transference from the legend; rather than have Hamlet display this power to see into the past, the Ghost instead provides the revelation. Shakespeare strengthens this element from Belleforest, which explains the role the Ghost has in unveiling its past (Wiley 24).

Unlike Saxo, Belleforest does however explicitly mention a Ghost, or shade, in his translation. According to Arthur Stabler, "A dramatist who was in search of raw materials for a play, and who was familiar with the traditions of Vergil and Seneca, would... have little difficulty in objectifying the ombre of Belleforest into a visible, acting ghost" (“King Hamlet's Ghost" 20). Shakespeare, aware of the high demand for supernatural elements, could then have easily incorporated this in his Hamlet. In regards to the resemblance of the two, Stabler states, "Belleforest's shade is precisely that of Prince Hamlet's murdered father. If this is pure 
coincidence, as it may be, then at the very least Belleforest must be credited with being the first to introduce a revenge ghost into the Hamlet story" (“King Hamlet's Ghost" 19).

Horwendil's ghost is mentioned twice in Belleforest's version. While in his mother's chamber, Amleth begins berating Geruth, seeking an admission from her of her disloyalty to Horwendil, and urging her to renounce her marriage to Fengi:

" $[\mathrm{I}] \mathrm{t}$ is unbridled lust which has led the daughter of Roric to embrace the tyrant Feng, without respect for the shade of Horwendil, indignant at such strange treatment, both that his brother treacherously killed him, and that his wife betrayed him in a cowardly manner, [she] whom he treated so well ..."

(Stabler, "King Hamlet's Ghost" 18)

Stabler again provides an explanation for this depiction:

"Further coincidences occur in striking similarities of attribute between the two spirits. In the first of the passages cited from Belleforest, for example, the shade of Horwendil is represented as indignant at the treatment which he (as a living man) had received; to wit, that his brother had treacherously murdered him, and that his wife had betrayed him. Shakespeare's Ghost expresses indignation, to put it mildly, for the same causes"

("King Hamlet's Ghost" 19)

Thus, the shade in Belleforest shares the same feelings as Hamlet's Ghost; both lack resolution in regards to their deaths and express anger towards it.

Belleforest's shade makes no further appearance in the story until after Amleth has

fulfilled his revenge. Before murdering him, Amleth states,

"[S]uch a violent death is the just recompense of people like you, and so go, and once in Hades, do not fail to tell your brother, whom you wickedly killed, that it is his son who makes you to bear this message, so that, comforted by this memory, his shade may rest peacefully among the blessed spirits, and hold me quit of the obligation which forced me to pursue this vengeance on my own blood ..."

(Stabler, "King Hamlet's Ghost" 19)

This passage implies that Amleth had an obligation to revenge his father's death brought about by his father. His motivation for acting can be tied to his father's shade, who urged him to avenge his death.

The same can be said for the Ghost in Hamlet. It too expresses shock and indignation at the nature of their deaths. In Hamlet, the Ghost describes his murder as "foul and most unnatural" 
(I, v, 31). He goes on to describe his indignation towards his death: “...Of life, of crown, of queen at once dispatched, cut off... unhouseled, disappointed, unaneled, no reck'ning made, but sent to my account with all my imperfections on my head. O horrible, O horrible, most horrible!” (8286). His speech reveals similarities to Belleforest's ghost. Since Shakespeare includes the character in Hamlet, he is able to provide further elaboration to his plight.

On its own, Shakespeare's Ghost could be seen as an addition solely made to appease the Elizabethan interests in the supernatural, likened to other ghosts present in revenge tragedies. Unlike other playwrights, however, Shakespeare's Ghost has a purpose. Clearly Horwendil's predecessor, the Ghost shares the sentiments outlined in Belleforest. His revelations of past events provide Hamlet with the revenge impetus. Additionally, this ability to reveal the past is an elaboration from the earlier tale.

The question still remains as to why the Ghost's claims need to be verified by Hamlet. Neither Belleforest nor Saxo describe Amleth's doubts over the act of his father's murder. Obviously, this is because both were witnesses to the event. However, "Hamlet does not credit the Ghost's story sufficiently to act upon it without further proof: 'I'll have grounds more relative than this' (II, ii, 632-633)" (Clark 77). An addition by Shakespeare, Hamlet's doubt of the Ghost, who serves as a representation of his father, delays the Ghost's mission.

In order to be more plausible, Hamlet needed to express doubt over the Ghost's claims in accordance with the Elizabethan's beliefs:

"If he had been one of the ignorant multitude, he would have regarded ghosts as the spirits of the departed and had no doubt that it was really his father who spoke to him. But Hamlet subscribed to the more educated belief that ghosts were instruments of the devil. He began by doubting its existence and insisted on seeing it himself. When he did see it, he was not convinced that it was not the product of his own imagination"

(Clark 77)

Shakespeare's Hamlet, portrayed as intelligent and deeply philosophical, must doubt the Ghost due to his nature. Amleth does not share this dilemma, as he witnesses the death and knows the 
shade is of his father in Belleforest's version. The discrepancy in the Ghost's validity is due then to the time frame in which Shakespeare was presenting his work.

Thus the Ghost in Hamlet cannot be seen as proof of Shakespeare's borrowing from Kyd or Marston; the inclusion of a Ghost in a play simply verifies a popular trend in Elizabethan time. Wishing to incorporate a Ghost of his own, Shakespeare decided to transform Horwendil, incorporating supernatural elements from the legend in the process as well. As with the other borrowed elements, examining the Ghost in Hamlet solely serves problematic. In order to show the complexities Shakespeare intended with its usage, a comparison with the Ur-Hamlet as well as with Elizabethan culture must be made. This reveals why Hamlet doubted the Ghost, and verifies his claim as Hamlet's father.

The Danish legend's claim as the Ur-Hamlet can thus further be corroborated by comparing it to Hamlet. Furthermore, answers to the questions that arise in Shakespeare involving Hamlet's madness and delay, the short sea voyage, and the Ghost lay in the original. Juxtaposing the two reveals complexities Shakespeare failed to include. Examining these aspects in the play itself yields no explanation. However, studying the earlier legend fills in the gaps created by Shakespeare's borrowing and conversion to a new genre.

\section{CONCLUSION}

Throughout this work, an archetypal approach to Hamlet has revealed the origin of the Ur-Hamlet to be the Danish legend of Amleth. Shakespeare borrows heavily from the legend, adapting his characters to a new format while maintain the requirements of the old. While other plays have been brought forth as potential candidates for Shakespeare's inspiration, none so wholly explain the play as the legend of Amleth. This leads to the conclusion that each of the playwrights chose to model their plays after these various legends, and not based off one another. Not only would this have proved impossible due to time constraints, the similarities present in both Hamlet and the Danish legend are too numerous to ignore. 
Not only the plot, but the characters themselves have roots in the original. Furthermore, comparing the Ur-Hamlet to Hamlet provides explanations for the curious aspects of the play which other supposed candidates for the Ur-Hamlet do not. Because of its remarkable similarities and ability to fill in the gaps left by Shakespeare, the Ur-Hamlet is then the archetypal story of "The Hero as Fool," represented by the legend of Amleth as translated by Saxo Grammaticus and Francois de Belleforest. 


\section{LIST OF REFERENCES}

Aguirre, Manuel. "Life, Crown, and Queen: Gertrude and the Theme of Sovereignty." The Review of English Studies 47.186 (1996): 163-74. JSTOR. Web.

Baldwin, T. W. "On the Chronology of Thomas Kyd's Plays." Modern Language Notes40.6 (1925): 343-49. Print.

Birenbaum, Harvey. "'To Be and Not to Be" the Archetypal Form of Hamlet." Pacific Coast Philogy 16.1 (1981): 19-28. Web.

Booker, Christopher. The Seven Basic Plots: Why We Tell Stories. London: Continuum, 2004. Print.

Brown, Roger, and Albert Gilman. "Politeness Theory and Shakespeare's Four Major Tragedies." Language in Society 18.02 (1989): 159-212. JSTOR. Web.

Bullough, G. "The Murder of Gonzago." The Modern Language Review 30.4 (1935): 433-44. JSTOR. Web.

Cary, Louise. "Hamlet Recycled or the Tragical History of the Prince's Prints." ELH 61.4 (1994): 783-805. JSTOR. Web.

Clark, Cumberland. Shakespeare and the Supernatural. New York: Haskell House, 1971. Print.

Cohen, Robert. "Shakespeare's Sixteen Year Old Hamlet." Educational Theater Journal25.2 (1973): 179-88.

De, Grazia Margreta. Hamlet without Hamlet. Cambridge: Cambridge UP, 2008. Print.

Draudt, Manfred. "The Comedy of "Hamlet"' Atlantis 24.1 (2002): 71-83. JSTOR. Web.

Frye, Northrop. Anatomy of Criticism; Four Essays. Atheneum: Princeton UP, 1969. Print.

Frye, Northup. "Hamlet." Northup Frye on Shakespeare. Binghampton: Yale UP, 1988. 82-100. Print.

Greaves, Richard L. "Apocalypse \& Armada in Kyd's Spanish Tragedy by Frank Ardolino Review By: Richard L. Greaves." Church History 65.4 (1996): 708-09.

Hansen, William F. Saxo Grammaticus \& the Life of Hamlet: a Translation, History, and Commentary. Lincoln: University of Nebraska, 1983. Print.

Hassel, R. Chris, Jr. "Hamlet's "Too, Too Solid Flesh"" The Sixteenth Century Journal 25.3 (1994): 609-22. JSTOR. Web. 
"Havelok the Dane." Four Romances of England: King Horn, Havelok the Dane, Bevis of Hampton, Athelston. Ed. Ronald B. Herzman, Graham Drake, and Eve Salisbury. Kalamazoo, Mich.: Medieval Institute Publications, Western Michigan University, 1999. 73-186. Print.

Jack, Albert E. "Thomas Kyd and the Ur-Hamlet." PMLA 20.4 (1905): 729-48. Print.

Johannesson, Kurt. The Renaissance of the Goths in Sixteenth-century Sweden: Johannes and Olaus Magnus as Politicians and Historians. Ed. James Larson. Berkeley: University of California, 1991. Print.

Kyd, Thomas. The Spanish Tragedy. Ed. Simon Trussler. London: Nick Hern, 1997. Print.

Lacan, Jacques, Jacques-Alain Miller, and James Hulbert. "Desire and the Interpretation of Desire in Hamlet." Yale French Studies 55-56 (1977): 11-52. JSTOR. Web

Lawrence, William W. "Hamlet and Fortinbras." Modern Language Association 61.3 (1946): 673-98. JSTOR. Web.

Lawrence, William W. "Hamlet's Sea Voyage." PMLA 59.1 (1944): 45-70. JSTOR. Web.

Lawrence, William W. "Ophelia's Heritage." The Modern Language Review 42.4 (1947): 409-16. Web.

Leeming, David Adams. From Olympus to Camelot: the World of European Mythology. Oxford [England]: Oxford UP, 2003. Print.

Lyons, Bridget G. "The Iconography of Ophelia." ELH 44.1 (1977): 60-74. JSTOR. The John Hopkins University Press. Web.

Maxwell, Julie. "Counter-Reformation Versions of Saxo: A New Source for "Hamlet?"' Renaissance Quarterly 57.2 (2004): 518-60. JSTOR. Web.

McGinn, Donald J. "A New Date for Antonio's Revenge." PMLA 53.1 (1938): 129-37.JSTOR. Web.

O'Donoghue, Heather. Old Norse-Icelandic Literature: a Short Introduction. Malden, MA: Blackwell, 2004. Print.

Porterfield, Sally F. Jung's Advice to the Players: a Jungian Reading of Shakespeare's Problem Plays. Westport, CT: Greenwood, 1994. Print.

Rank, Otto. The Myth of the Birth of the Hero: A Psychological Exploration of Myth. Trans. Gregory C. Richter and E. James Lieberman. Baltimore, MD: Johns Hopkins UP, 2004. Print.

Root, Robert K. Classical Mythology in Shakespeare. New York: Gordian, 1965. Print. 
Sadowski, Piotr. "The "Cosmic Caesura" Theme in the Hamlet Story: A Study in Comparative Mythology." History of Religions 26.3 (1987): 295-308. Web.

Santillana, Giorgio De, and Hertha Von Dechend. Hamlet's Mill. Boston: David R. Godine, 1977. Hamlet's Mill. PheonixandTurtle. Web.

$<$ http://www.bibliotecapleyades.net/hamlets_mill/hamletmill.htm\#top>.

Schwartz, Sheila. "The Idea of the Hero." The English Journal 58.1 (1969): 82-86. JSTOR. National Council of Teachers of English. Web.

Shakespeare, William. "The Tragedy of Hamlet, Prince of Denmark." The Riverside Shakespeare. Ed. G. Blakemore Evans. Boston: Houghton Mifflin, 1974. 1135-197. Print.

Showalter, Elaine S. "Representing Ophelia: Women, Madness, and the Responsibilities of Feminist Criticism." Hamlet. New York: W. W. Norton and, 2011. 281-97. Print.

Sibley, Carol. "Archetypes in Literature." Reading. Archetypes in Literature. Minnesota State University, Mankato. Web.

$<$ web.mnstate.edu/sibley/.../Archetypes\%20in\%20Literature.doc $>$.

Smith, John H., Louis D. Pizer, and Edward K. Kaufman. "Hamlet, Antonio's Revenge, and the Ur-Hamlet." Shakespeare Quarterly 9.4 (1958): 493-98. Web.

Snider, D. J. "HAMLET." The Journal of Speculative Psychology 7.3 (1873): 78-89.JSTOR. Web.

Stabler, Arthur P. "King Hamlet's Ghost in Belleforest?" PMLA 77.1 (1962): 18-20. JSTOR. Web.

Stabler, Arthur. P. "Melancholy, Ambition, and Revenge in Belleforest's Hamlet." PMLA 81.3 (1966): 207-13. JSTOR. Web.

States, Bert O. "The Persistence of the Archetype." Critical Inquiry 7.2 (1980): 333. Web.

Stephenson, Henry T. "Hamlet's Mouse-Trap." The Sewanee Review 13.1 (1905): 30-35. JSTOR. Web.

Stevens, Martin. "Hamlet and the Pirates: A Critical Reconsideration." Shakespeare Quarterly 26.3 (1975): 276-84. JSTOR. Web.

Sugg, Richard. "Archetype." The Princeton Encyclopedia of Poetry and Poetics 4 (2012): 76-79. Print.

Wiley, Edwin. "Hamlet." A Study of the Supernatural in Three Plays of Shakespeare. Folcroft: Folcroft Library Editions, 1971. 13-33. Print.

Williamson, Claude. "Hamlet." International Journal of Ethics 33.1 (1922): 85-100.JSTOR. Web. 